Supporting Information

\title{
Facile Synthesis of Hybrid Silica Nanoparticles Grafted with Helical Poly(phenyl isocyanide) and Their Enantioselective Crystallization Ability
}

Li Yang, Yang Tang, Na Liu, Chun-Hua Liu, Yunsheng Ding, and Zong-Quan Wu*

Department of Polymer Science and Engineering, School of Chemistry and Chemical Engineering, Hefei University of Technology and Anhui Key Laboratory of Advanced Functional Materials and Devices, Hefei 230009, China 


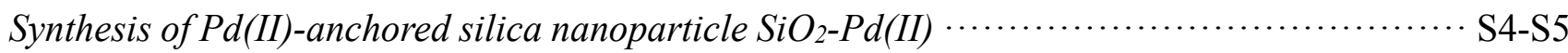

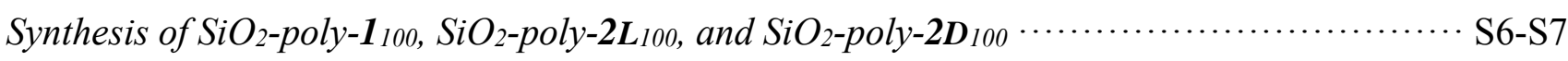

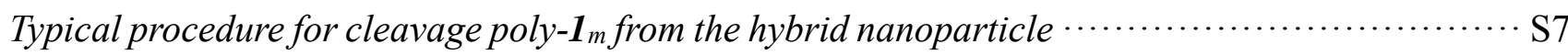

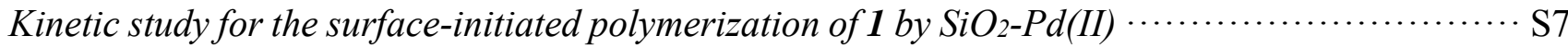

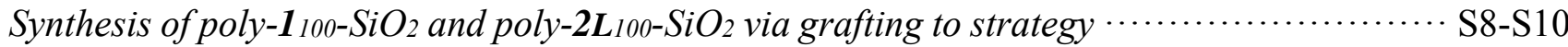

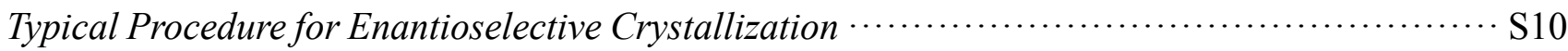

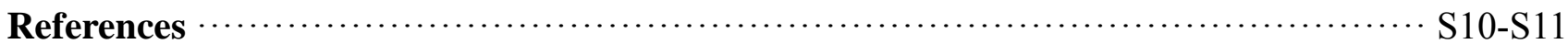

Table S1. $M_{\mathrm{n}}$ and $M_{\mathrm{w}} / M_{\mathrm{n}}$ data for poly-1 100 etched from $\mathrm{SiO}_{2}-$ poly-1 $100 \ldots \ldots \ldots \ldots \ldots \ldots \ldots \ldots \ldots, \mathrm{S} 12$

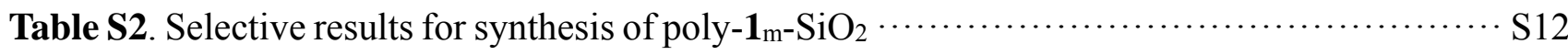

Figure S1-S2. ${ }^{1} \mathrm{H}$ NMR and FT-IR spectra of poly-1 100 etched from $\mathrm{SiO}_{2}-$ poly-1 $100 \ldots \ldots \ldots \cdots \cdot \mathrm{S} 13$

Figure S3. SEC and plots of $M_{\mathrm{n}}$ and $M_{\mathrm{w}} / M_{\mathrm{n}}$ of etched poly-1 $\mathbf{1}_{\mathrm{m}}$ with the initial feed ratio of monomer

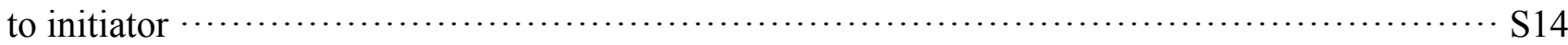

Figure S4. DLS for bare silica nanoparticle and the resulting $\mathrm{SiO}_{2}-$ poly-1 $\mathbf{1}_{\mathrm{m}} \cdots \ldots \ldots \ldots \ldots \ldots \ldots \ldots, \mathrm{S} 14$

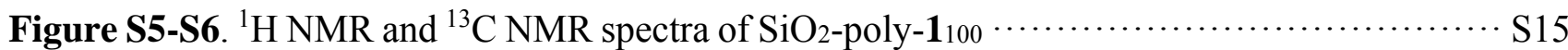

Figure S7. Plots of $M_{\mathrm{n}}$ and $M_{\mathrm{w}} / M_{\mathrm{n}}$ of etched poly-1 $\mathrm{m}$ with the conversion of $\mathbf{1} \cdots \ldots \ldots \ldots \ldots \ldots \ldots, \mathrm{S} 16$

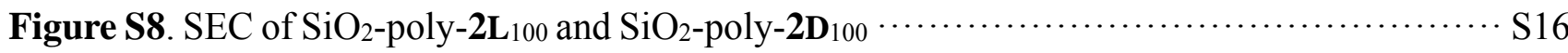

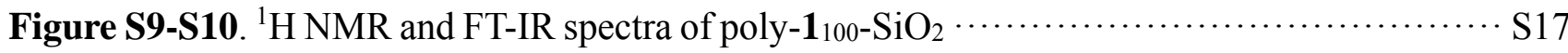

Figure S11-S13. SEC, FT-IR and DLS spectra of poly-2L $\mathbf{L}_{100}-\mathrm{OH}$ and poly-2L $\mathrm{L}_{100}-\mathrm{SiO}_{2} \cdots \cdots \cdot \mathrm{S} 18-\mathrm{S} 19$

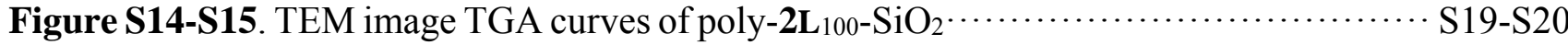

Figure S16. Time-dependent CD and UV-vis of Boc-alanine induced by poly-2 $\mathrm{L}_{100}-\mathrm{SiO}_{2} \cdots \cdots \cdots \cdot \mathrm{S} 20$

Figure S17. CD and UV-vis of Boc-alanine induced by chiral $\mathrm{SiO}_{2}-$ poly-2 $\mathrm{L}_{100} \cdots \cdots \cdots \cdots \cdots \cdots \cdots \cdot \mathrm{S} 21$

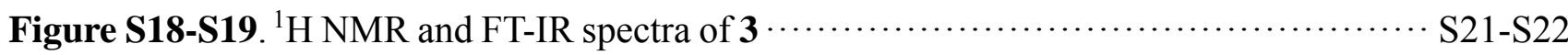

Figure S20-S22. ${ }^{1} \mathrm{H}$ NMR, ${ }^{13} \mathrm{C}$ NMR and FT-IR spectra of TEOS-Pd(II) ….............. S22-S23

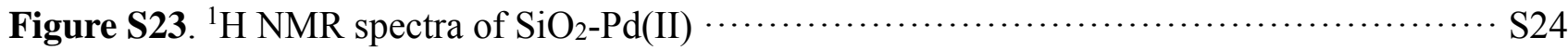

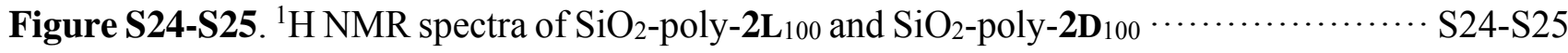

Figure S26-S27. ${ }^{1} \mathrm{H}$ NMR spectra of poly-1 $\mathbf{1}_{100-} \mathrm{SiO}_{2}$ and poly-2L $100-\mathrm{SiO}_{2} \cdots \cdots \cdots \cdots \cdots \cdot \ldots \cdot \mathrm{S} 25-\mathrm{S} 26$ 
General consideration. The ${ }^{1} \mathrm{H},{ }^{13} \mathrm{C}$ and ${ }^{31} \mathrm{P}$ NMR spectra were recorded using a Bruker 600 or 400 $\mathrm{MHz}$ spectrometer $\{\mathrm{H}\}$. Size exclusion chromatography (SEC) was performed on Waters 1515 pump and Waters 2414 differential refractive index (RI) detector (set at $40{ }^{\circ} \mathrm{C}$ ) using a series of linear Styragel HR1, HR2 and HR4 columns. Molecular weight $\left(M_{\mathrm{n}}\right)$ and polydispersity $\left(M_{\mathrm{w}} / M_{\mathrm{n}}\right)$ data are reported relative to polystyrene standards. The eluent was tetrahydrofuran (THF) at a flow rate of 0.3 mL/min. FT-IR spectra were recorded on Perkin-Elmer Spectrum BX FT-IR system using KBr pellets. UV-vis spectra were performed on a UNIC $4802 \mathrm{UV} / \mathrm{VIS}$ double beam spectrophotometer in $1.0 \mathrm{~cm}$ length quartz cell. Circular dichroism (CD) spectra were obtained in a $1.0 \mathrm{~mm}$ quartz cell at $25{ }^{\circ} \mathrm{C}$ using a JASCO J1500 spectropolarimeter. The polymer concentration was calculated on the basis of the monomer units and was $0.20 \mathrm{~g} / \mathrm{L}$. The optical rotations were measured in $\mathrm{CHCl}_{3}$ at room temperature using a $10.0 \mathrm{~cm}$ quartz cell on a WZZ-2B polarimeter. Transmission electron microscopy (TEM) was performed on a JEM-2100F operating at $200 \mathrm{kV}$ accelerating voltage. Scanning electron microscopy (SEM) was performed on a SU8020 operating at $5.0 \mathrm{kV}$ accelerating voltage. Dynamic light scattering (DLS) was recorded using a Nano-ZS 90 Zetasizer of Malvern (UK) instrument. Thermogravimetric analysis (TGA) was carried out with a Q50 TGA at a scanning rate of $10{ }^{\circ} \mathrm{C} / \mathrm{min}$ in air. All solvents were purchased from Sonopharm Co. Ltd., and were purified by standard procedure before used. All chemicals were obtained from Aladdin, Sinopharm, and Sigma-Aldrich Chemical Co. Ltd., and were used as received without further purification otherwise denoted. Phenyl isocyanide monomers 1, 2L and 2D, and the trans-bis(triethylphosphine)-(3-hydroxyprop-1-yn-1-yl)palladium(II) chloride were prepared according to the reported literatures and the structures were confirmed by ${ }^{1} \mathrm{H}$ NMR. ${ }^{1}$ 
Synthesis of [(2-propynylcarbamate)propyl] triethoxysilane (3): This compound was synthesized followed the reported literatures with slight modifications..$^{2}$ In a dried flask, propargyl alcohol $(3.00 \mathrm{~g}$, $53.5 \mathrm{mmol})$ and triethylamine $(5.00 \mathrm{~g}, 49.5 \mathrm{mmol})$ were dissolved in $\mathrm{CH}_{2} \mathrm{Cl}_{2}(25 \mathrm{~mL})$. The mixture was then cooled in an ice bath. To this cooled solution, a solution of triethoxy(3isocyanatopropyl)silane $(11.87 \mathrm{~g}, 48.0 \mathrm{mmol})$ in $\mathrm{CH}_{2} \mathrm{Cl}_{2}(15 \mathrm{~mL})$ was added dropwise under dry nitrogen. After the addition, the reaction mixture was allowed to stir at room temperature for $5 \mathrm{~h}$. Then filtered off the insolvable materials, the filtrate was evaporated to dryness under reduced pressure to afford 3 as a colorless oil. ${ }^{1} \mathrm{H}$ NMR $\left(600 \mathrm{MHz}, \mathrm{CDCl}_{3}, 25^{\circ} \mathrm{C}\right): \delta 5.11(\mathrm{~s}, 1 \mathrm{H}, \mathrm{NH}), 4.64(\mathrm{~d}, J=1.8 \mathrm{~Hz}$, $\left.2 \mathrm{H}, \mathrm{CO}_{2} \mathrm{CH}_{2}\right), 3.79\left(\mathrm{q}, J_{1}=7.2 \mathrm{~Hz}, J_{2}=14.4 \mathrm{~Hz}, 6 \mathrm{H}, \mathrm{OC}_{\underline{H}} \mathrm{CH}_{3}\right), 3.19-3.15\left(\mathrm{~m}, 2 \mathrm{H}, \mathrm{C}_{2} \mathrm{NH}\right), 2.44(\mathrm{t}$, $J=2.4 \mathrm{~Hz}, 1 \mathrm{H}, \mathrm{CH}), 1.62-1.58\left(\mathrm{~m}, 2 \mathrm{H}, \mathrm{C}_{2} \mathrm{CH}_{2} \mathrm{NH}\right), 1.21-1.19\left(\mathrm{t}, J=7.2 \mathrm{~Hz}, 9 \mathrm{H}, \mathrm{OCH}_{2} \mathrm{CH}_{3}\right), 0.62-$

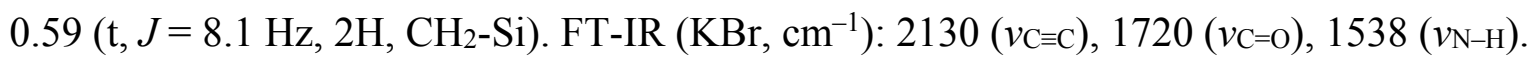

Synthesis of TEOS-Pd(II): Compound $3(1.00 \mathrm{~g}, 3.29 \mathrm{mmol})$ was treated with transbis(triethylphosphine)palladium dichloride $(1.36 \mathrm{~g}, 3.29 \mathrm{mmol})$ in the presence of copper(I) chloride (46.5 mg, $0.47 \mathrm{mmol})$ as catalyst in diethylamine $(160 \mathrm{~mL})$ and dichloromethane $(40 \mathrm{~mL})$. The mixture was stirred at room temperature for $3 \mathrm{~h}$. After the solvent was removed by evaporation under reduced pressure. The isolated product was recrystallized from petrol ether and methanol to afford TEOS-Pd(II) as a pale yellow solid (2.03 g, $86 \%$ yield). ${ }^{1} \mathrm{H}$ NMR (600 MHz, $\left.\mathrm{CDCl}_{3}, 25{ }^{\circ} \mathrm{C}\right): \delta 4.86(\mathrm{~s}, 1 \mathrm{H}, \mathrm{NH})$, $4.68\left(\mathrm{~d}, J=1.8 \mathrm{~Hz}, 2 \mathrm{H}, \mathrm{CO}_{2} \mathrm{CH}_{2}\right), 3.80\left(\mathrm{q}, J_{1}=7.2 \mathrm{~Hz}, J_{2}=14.4 \mathrm{~Hz}, 6 \mathrm{H}, \mathrm{OC}_{2} \mathrm{CH}_{3}\right), 3.18-3.15(\mathrm{~m}$, $\left.2 \mathrm{H}, \underline{\mathrm{C}}_{2} \mathrm{NH}\right), 1.92-1.89\left(\mathrm{~m}, 12 \mathrm{H}, \mathrm{PC}_{\underline{H}} \mathrm{CH}_{3}\right), 1.62-1.57\left(\mathrm{~m}, 2 \mathrm{H}, \underline{\mathrm{C}}_{2} \mathrm{CH}_{2} \mathrm{NH}\right), 1.22-1.14(\mathrm{~m}, 27 \mathrm{H}$, $\mathrm{OCH}_{2} \underline{\mathrm{CH}}_{3}$ and $\left.\mathrm{PC}_{2} \mathrm{CH}_{3}\right), 0.62-0.59\left(\mathrm{t}, J=8.1 \mathrm{~Hz}, 2 \mathrm{H}, \mathrm{CH}_{2}-\mathrm{Si}\right) .{ }^{13} \mathrm{C} \mathrm{NMR}\left(150 \mathrm{MHz}, \mathrm{CDCl}_{3}, 25{ }^{\circ} \mathrm{C}\right)$ : $\delta 158.76,102.64,92.77,80.04,60.96,57.52,45.94,32.22,25.92,20.84,17.69,10.84,10.15,3.56 .{ }^{31} \mathrm{P}$ NMR $\left(121.5 \mathrm{MHz}, \mathrm{CDCl}_{3}, 25^{\circ} \mathrm{C}\right): \delta 17.60 . \mathrm{FT}-\mathrm{IR}\left(\mathrm{KBr}, \mathrm{cm}^{-1}\right): 2980\left(v_{\mathrm{C}-\mathrm{H}}\right), 2935\left(v_{\mathrm{C}-\mathrm{H}}\right), 2876\left(v_{\mathrm{C}-\mathrm{H}}\right)$, 
$2130\left(v_{\mathrm{C}=\mathrm{C}}\right), 1728\left(v_{\mathrm{C}=\mathrm{O}}\right), 1538\left(v_{\mathrm{N}-\mathrm{H}}\right) . \mathrm{MS} \mathrm{m} / \mathrm{z}$ calcd for $\mathrm{C}_{25} \mathrm{H}_{54} \mathrm{ClNO}_{5} \mathrm{P}_{2} \mathrm{PdSi}[\mathrm{M}+\mathrm{H}]^{+}: 679.1479$; Found: 679.1502. Anal. Calcd (\%) for $\mathrm{C}_{25} \mathrm{H}_{54} \mathrm{ClNO}_{5} \mathrm{P}_{2} \mathrm{PdSi}$ : C, 44.17; H, 7.95; N, 2.06; Found (\%): C, 44.16; H, 7.96; N, 2.02.

Synthesis of bare silica nanoparticles: The bare silica nanoparticles ( $\sim 70 \mathrm{~nm}$ in diameter) was synthesized according to the reported literature. ${ }^{3}$ Ammonium hydroxide (25\% in water, $14.02 \mathrm{~g}$ ) and tetraethoxysilane $(7.18 \mathrm{~g}$ ) were dissolved in ethanol (each $5 \mathrm{~mL}$ ) separately and were added into a 500 $\mathrm{mL}$ flask containing $190 \mathrm{~mL}$ of ethanol. The concentrations of $\mathrm{NH}_{3}$, tetraethoxysilane, and water in the solution were $0.44,0.15$, and $3.03 \mathrm{M}$, respectively. After the mixture was stirred vigorously at room temperature for $4 \mathrm{~h}$, the nanoparticles were isolated by centrifugation (6000 rpm), re-dispersed in ethanol, and centrifugated again. The washing process was repeated with ethanol one more time, water four times, and ethanol again. The nanoparticles were dried with a stream of air $(2.09 \mathrm{~g}, 98 \%$ yield). FT-IR $\left(\mathrm{KBr}, \mathrm{cm}^{-1}\right): 1100(v \mathrm{Si}-\mathrm{O}), 945(v \mathrm{Si}-\mathrm{OH}), 800(v \mathrm{Si}-\mathrm{O}-\mathrm{Si}), 465(v \mathrm{Si}-\mathrm{O})$.

Synthesis of Pd(II)-anchored silica nanoparticles ( $\mathrm{SiO}_{2}-\mathrm{Pd}(\mathrm{II})$ ): To a $250 \mathrm{~mL}$ round bottom flask was added ammonium hydroxide $(25 \%$ in water, $5 \mathrm{~mL})$, deionized water $(70 \mathrm{~mL})$ and methanol $(100$ $\mathrm{mL})$, and stirred for $10 \mathrm{~min}$ at room temperature. TEOS-Pd(II) $(0.50 \mathrm{~g}, 0.73 \mathrm{~mol})$ was then added to the stirring solution, at which point the reaction mixture became cloudy and white. After 20 min of stirring, silica nanoparticles (1.00 g) were added and the suspension was stirred overnight. The nanoparticles were purified by repeated centrifugation and re-dispersion in ethanol $(40 \mathrm{~mL})$ and THF (20 mL). Removal of solvent by evaporation under reduced pressure, and drying under vacuum at 30 ${ }^{\circ} \mathrm{C}$ overnight, afforded the desired $\mathrm{SiO}_{2}-\mathrm{Pd}(\mathrm{II})$ as a pale yellow powder $(0.98 \mathrm{~g}, 76 \%$ yield $) .{ }^{1} \mathrm{H} \mathrm{NMR}$ $\left(400 \mathrm{MHz}, \mathrm{CDCl}_{3}, 25^{\circ} \mathrm{C}\right): \delta 5.33(\mathrm{~s}, 1 \mathrm{H}, \mathrm{NH}), 4.69\left(\mathrm{~d}, J=2.1 \mathrm{~Hz}, 2 \mathrm{H}, \mathrm{CO}_{2} \mathrm{CH}_{2}\right), 3.03-3.00(\mathrm{~m}, 2 \mathrm{H}$, 
$\left.\mathrm{C}_{2} \mathrm{NH}\right), 1.72-1.62\left(\mathrm{~m}, 12 \mathrm{H}, \mathrm{PC}_{\underline{H}} \mathrm{CH}_{3}\right), 1.43-1.42\left(\mathrm{~m}, 2 \mathrm{H}, \underline{\mathrm{C}}_{2} \mathrm{CH}_{2} \mathrm{NH}\right), 1.25-1.15(\mathrm{~m}, 18 \mathrm{H}$, $\left.\mathrm{PCH}_{2} \mathrm{CH}_{3}\right), 0.89-0.86\left(\mathrm{t}, J=8.0 \mathrm{~Hz}, 2 \mathrm{H}, \mathrm{CH}_{2}-\mathrm{Si}\right) .{ }^{31} \mathrm{P} \mathrm{NMR}\left(121.5 \mathrm{MHz}, \mathrm{CDCl}_{3}, 25{ }^{\circ} \mathrm{C}\right): \delta 17.60 . \mathrm{FT}-$ IR $\left(\mathrm{KBr}, \mathrm{cm}^{-1}\right): 2130\left(v_{\mathrm{C} \equiv \mathrm{C}}\right), 1720\left(v_{\mathrm{C}=\mathrm{O}}\right), 1538\left(v_{\mathrm{N}-\mathrm{H}}\right), 1100\left(v_{\mathrm{Si}-\mathrm{O}}\right), 465\left(v_{\mathrm{Si}-\mathrm{O}}\right)$.

Synthesis of hybrid silica nanoparticles $\mathrm{SiO}_{2}$-poly-1 100 via "grafting from" strategy: A $10 \mathrm{~mL}$ oven dried and nitrogen-filled flask was charged with monomer 1 (100 mg, $0.35 \mathrm{mmol})$, THF (1.64 mL), and a stir bar. To this stirring solution was added a solution of $\mathrm{SiO}_{2}-\mathrm{Pd}(\mathrm{II})$ in $\mathrm{THF}(0.035 \mathrm{M}, 0.10 \mathrm{~mL})$ via a microsyringe at $25^{\circ} \mathrm{C}$. The concentrations of monomer 1 and $\mathrm{Pd}(\mathrm{II})$ unit were 0.2 and $0.002 \mathrm{M}$, respectively $\left([\mathbf{1}]_{0} /[\mathrm{Pd}]_{0}=100\right)$. The reaction flask was then immersed into a preheated oil bath at $55^{\circ} \mathrm{C}$ and stirred for $16 \mathrm{~h}$. After cooled to room temperature, the polymerization solution was precipitated into a large amount of methanol, collected by centrifugation, and dried in vacuum at room temperature overnight, afforded $\mathrm{SiO}_{2}$-poly-1 100 in $90 \%$ yield. The yield was determined by gravimetric method through divided the weight of resulting hybrid silica nanoparticle by the total amount of bare silica nanoparticle and the monomer. SEC: $M_{\mathrm{n}}=2.96 \times 10^{4}, M_{\mathrm{w}} / M_{\mathrm{n}}=1.14 .{ }^{1} \mathrm{H} \mathrm{NMR}\left(600 \mathrm{MHz}, \mathrm{CDCl}_{3}\right.$, $25{ }^{\circ} \mathrm{C}$ ): $\delta 7.33$ (brs, $2 \mathrm{H}$, aromatic), 5.77 (brs, 2H, aromatic), 4.07-3.84 (brs, $2 \mathrm{H}, \mathrm{OCH}_{2}$ ), 1.51-0.84 (brs, $19 \mathrm{H}, \mathrm{CH}_{2}$ and $\left.\mathrm{CH}_{3}\right) .{ }^{13} \mathrm{C} \mathrm{NMR}\left(150 \mathrm{MHz}, \mathrm{CDCl}_{3}, 25{ }^{\circ} \mathrm{C}\right): \delta 164.95,162.55,150.44,129.78$, $127.27,117.09,64.88,31.88,29.65,29.58,29.44,29.30,28.61,25.99,22.63,14.10 .{ }^{31} \mathrm{P}$ NMR $(121.5$ $\left.\mathrm{MHz}, \mathrm{CDCl}_{3}, 25^{\circ} \mathrm{C}\right): \delta 14.30 . \mathrm{FT}-\mathrm{IR}\left(\mathrm{KBr}, \mathrm{cm}^{-1}\right): 2960\left(v_{\mathrm{C}-\mathrm{H}}\right), 2930\left(v_{\mathrm{C}-\mathrm{H}}\right), 2860\left(v_{\mathrm{C}-\mathrm{H}}\right), 1720\left(v_{\mathrm{C}=\mathrm{O}}\right)$, $1630(v \mathrm{C}=\mathrm{N}), 1538\left(v_{\mathrm{N}-\mathrm{H}}\right), 1100\left(v_{\mathrm{Si}-\mathrm{O}}\right), 465\left(v_{\mathrm{Si}-\mathrm{O}}\right)$.

Synthesis of $\mathrm{SiO}_{2}-$ poly-2L 100 : This hybrid nanoparticle was prepared in $78 \%$ yield under the same procedure to that of $\mathrm{SiO}_{2}$-poly-1 100 by using $2 \mathbf{L}$ monomer. SEC: $M_{\mathrm{n}}=3.28 \times 10^{4} \mathrm{Da}, M_{\mathrm{w}} / M_{\mathrm{n}}=1.18$. ${ }^{1} \mathrm{H}$ NMR $\left(600 \mathrm{MHz}, \mathrm{CDCl}_{3}, 25{ }^{\circ} \mathrm{C}\right): \delta 8.82-7.65$ (brs, 1H, NH), 6.94-5.69 (brs, 4H, aromatic), 4.89- 
4.25 (brs, $\mathrm{H}, \mathrm{CH}$ ), 4.24-3.72 (brs, $2 \mathrm{H}, \mathrm{CH}_{2}$ ), 1.62-1.30 (brs, $19 \mathrm{H}, \mathrm{CH}_{2}$ and $\mathrm{CH}_{3}$ ), 0.45-1.12 (brs, 3H, $\left.\mathrm{CH}_{3}\right) \cdot[\alpha]^{25} \mathrm{D}-1235\left(c=0.1, \mathrm{CHCl}_{3}\right) . \mathrm{FT}-\mathrm{IR}\left(\mathrm{KBr}, \mathrm{cm}^{-1}\right): 2960\left(v_{\mathrm{C}-\mathrm{H}}\right), 2930\left(v_{\mathrm{C}-\mathrm{H}}\right), 2860\left(v_{\mathrm{C}-\mathrm{H}}\right), 1720$ $\left(v_{\mathrm{C}=\mathrm{O}}\right), 1630\left(v_{\mathrm{C}=\mathrm{N}}\right), 1100\left(v_{\mathrm{Si}-\mathrm{O}}\right), 465\left(v_{\mathrm{Si}-\mathrm{O}}\right)$.

Synthesis of $\mathrm{SiO}_{2}-$ poly-2D $\mathbf{D}_{100}$ : This hybrid nanoparticle was prepared in $78 \%$ yield under the same procedure to that of $\mathrm{SiO}_{2}$-poly-2L100 by using 2D monomer. SEC: $M_{\mathrm{n}}=3.29 \times 10^{4} \mathrm{Da}, M_{\mathrm{w}} / M_{\mathrm{n}}=1.18$. ${ }^{1} \mathrm{H}$ NMR $\left(600 \mathrm{MHz}, \mathrm{CDCl}_{3}, 25{ }^{\circ} \mathrm{C}\right): \delta 8.82-7.65$ (brs, 1H, NH), 6.94-5.68 (brs, 4H, aromatic), 4.964.25 (brs, $\mathrm{H}, \mathrm{CH}$ ), 4.23-3.65 (brs, $2 \mathrm{H}, \mathrm{CH}_{2}$ ), 1.61-1.30 (brs, $19 \mathrm{H}, \mathrm{CH}_{2}$ and $\mathrm{CH}_{3}$ ), 0.89 (brs, 3H, $\mathrm{CH}_{3}$ ).

Procedure for cleavage poly-1 $\mathrm{m}$ from the hybrid silica nanoparticle: This experiment was performed followed the reported procedure with slight modifications. ${ }^{4}$ Taking hybrid silica nanoparticle $\mathrm{SiO}_{2}-$ poly-1 100 as an example: $\mathrm{SiO}_{2}$-poly-1 $100(55 \mathrm{mg})$ was dissolved in $\mathrm{THF}(8 \mathrm{~mL})$ in a $20 \mathrm{~mL}$ plastic vial. Hydrofluoric acid (HF, $\sim 50 \%$ aq., $1 \mathrm{~mL}$ ) was added to the stirring solution. The mixture was stirred at room temperature for $6 \mathrm{~h}$. After a half of the solvent was removed by evaporation under reduced pressure, it was precipitated into a large amount of methanol. The precipitated solid was isolated via filtration, washed with methanol, and dried in vacuum, afforded poly-1 100 was isolated as a yellow solid. The structure of poly-1 100 was characterized by ${ }^{1} \mathrm{H}$ NMR, FT-IR and SEC analyses.

Kinetic study for the surface-initiated polymerization of 1 by $\mathrm{SiO}_{2}-\mathrm{Pd}(\mathrm{II})$ : Monomer 1 (60.0 mg, $0.21 \mathrm{mmol})$ and a standard polystyrene $\left(M_{\mathrm{n}}=2620, M_{\mathrm{w}} / M_{\mathrm{n}}=1.06,10.0 \mathrm{mg}\right)$ were placed in a dry ampule, which was then evacuated on a vacuum line and flushed with dry nitrogen. After the evacuation-flush procedure had been repeated three times, a three-way stopcock was attached to the ampule, and dry THF (1.10 mL) was added via a syringe. To this was added a solution of $\mathrm{SiO}_{2}-\mathrm{Pd}(\mathrm{II})$ in THF $(0.021 \mathrm{M}, 0.05 \mathrm{~mL})$ via a microsyringe at $25^{\circ} \mathrm{C}$. The concentrations of 1 and the $\operatorname{Pd}(\mathrm{II})$ unit 
were 0.2 and $0.002 \mathrm{M}$, respectively. The mixture was then stirred under a dry nitrogen atmosphere and heated to $55^{\circ} \mathrm{C}\left([\mathbf{1}]_{0} /[\mathrm{Pd}]_{0}=100\right)$. The conversion of $\mathbf{1}$ was followed by measuring the SEC of the aliquots taken out from the reaction mixture at appropriate time intervals. The peak area of the unreacted 1 relative to that of the internal standard (polystyrene) was used for the estimation of the conversion of 1 on the basis of the linear calibration curve. The $M_{\mathrm{n}}$ and $M_{\mathrm{w}} / M_{\mathrm{n}}$ were estimated by SEC and reported as equivalent to polystyrene standard.

Synthesis of poly-1 100-OH: A $10 \mathrm{~mL}$ oven-dried flask was charged with monomer 1 (100 mg, 0.35 mmol), THF (1.64 mL) and a stir bar. To this stirring solution was added a solution of HO-terminated alkyne-Pd(II) complex, trans-bis(triethyl phosphine)-(3-hydroxyprop-1-yn-1-yl)palladium(II) chloride in THF $(0.035 \mathrm{M}, 0.10 \mathrm{~mL})$ via a microsyringe at room temperature. The concentrations of monomer 1 and the $\mathrm{Pd}(\mathrm{II})$ initiator were 0.2 and $0.002 \mathrm{M}$, respectively $\left([\mathbf{1}]_{0} /[\mathrm{Pd}]_{0}=100\right)$. The reaction flask was then immersed into a preheated oil bath at $55^{\circ} \mathrm{C}$ and stirred for $16 \mathrm{~h}$. After cooled to room temperature, the polymerization solution was precipitated into a large amount of methanol. The solid was collected by centrifugation, and dried in vacuum at room temperature overnight, afford poly-1 $\mathbf{1}_{100}-$ $\mathrm{OH}$ as light yellow solid (92 mg, 92\% yield). SEC: $M_{\mathrm{n}}=2.80 \times 10^{4}, M_{\mathrm{w}} / M_{\mathrm{n}}=1.16 .{ }^{1} \mathrm{H}$ NMR $(600$ $\mathrm{MHz}, \mathrm{CDCl}_{3}, 25^{\circ} \mathrm{C}$ ): $\delta 7.31$ (brs, $2 \mathrm{H}$, aromatic), 5.74 (brs, $2 \mathrm{H}$, aromatic), 4.50-3.50 (brs, $2 \mathrm{H}, \mathrm{OCH}_{2}$ ), $1.95-0.85$ (brs, $19 \mathrm{H}, \mathrm{CH}_{2}$ and $\mathrm{CH}_{3}$ ).

Synthesis of poly-2L $100-O H$ : This left-handed helical poly-2L $100-O H$ was synthesized followed the reported literature. ${ }^{1 \mathrm{c}} \mathrm{SEC}: M_{\mathrm{n}}=3.82 \times 10^{4}, M_{\mathrm{w}} / M_{\mathrm{n}}=1.16 .{ }^{1} \mathrm{H} \mathrm{NMR}\left(600 \mathrm{MHz}, \mathrm{CDCl}_{3}, 25{ }^{\circ} \mathrm{C}\right):{ }^{1} \mathrm{H}$ NMR (600 MHz, $\left.\mathrm{CDCl}_{3}, 25^{\circ} \mathrm{C}\right): \delta 8.82-7.65$ (brs, 1H, NH), 6.94-5.68 (brs, 4H, aromatic), 4.55 (brs, H, CH), 4.10 (brs, 2H, $\mathrm{CH}_{2}$ ), 1.62-1.30 (brs, $19 \mathrm{H}, \mathrm{CH}_{2}$ and $\mathrm{CH}_{3}$ ), 0.89 (brs, $3 \mathrm{H}, \mathrm{CH}_{3}$ ). 
Synthesis of poly-1 100-TEOS: To a $100 \mathrm{~mL}$ round bottom flask, poly-1 ${ }_{100}-\mathrm{OH}(0.50 \mathrm{~g})$, trimethylamine $(5 \mathrm{~mL})$ and dichloromethane $(5 \mathrm{~mL})$ were added, and the suspension was stirred at room temperature for $10 \mathrm{~min}$. A solution of triethoxy(3-isocyanatopropyl)silane $(1.50 \mathrm{~g}, 6.06 \mathrm{mmol})$ in dichloromethane $(15 \mathrm{~mL})$ was added dropwise to the stirring solution under dry nitrogen. The reaction mixture was allowed to stir at $25{ }^{\circ} \mathrm{C}$ for $12 \mathrm{~h}$ and then precipitated into a large amount of methanol. The solid was collected by centrifugation, and dried in vacuum at room temperature overnight, afforded the desired poly-1 ${ }_{100}$-TEOS as a yellow powder $(0.40 \mathrm{~g}, 80 \%$ yield $)$. The poly$\mathbf{1}_{100}$-TEOS was directly used in the next step without further characterization.

Synthesis of poly-2L $100-T E O S$ : This polymer was synthesized in $90 \%$ yield followed the same procedure to that of poly-1 $100-$ TEOS using poly-2L $100-\mathrm{OH}$, and was used directly in the next step without further characterization.

Synthesis of poly-1 100-SiO 2 hybrid silica nanoparticle via "grafting to" strategy: To a $100 \mathrm{~mL}$ round bottom flask were added ammonium hydroxide $(25 \%$ in water, $5.00 \mathrm{~mL})$, deionized water $(70 \mathrm{~mL})$ and methanol $(100 \mathrm{~mL})$. The mixed solution was stirred at room temperature for $10 \mathrm{~min}$. Poly-1 $100-$ TEOS $(0.40 \mathrm{~g})$ was then added to the stirring solution. After stirred for $20 \mathrm{~min}$ at room temperature, bare silica nanoparticle (1.00 g) was added, and the suspension was stirred overnight. The resulting hybrid nanoparticle was purified by repeated centrifugation and re-dispersion in ethanol (40 $\mathrm{mL})$ and THF $(20 \mathrm{~mL})$. Dried under vacuum at $30{ }^{\circ} \mathrm{C}$ overnight, afforded the desired poly-1 ${ }_{100}-\mathrm{SiO}_{2}$ hybrid silica nanoparticle as a yellow powder $(0.36 \mathrm{~g}, 90 \%$ yield $)$. SEC: $M_{\mathrm{n}}=3.95 \times 10^{4}, M_{\mathrm{w}} / M_{\mathrm{n}}=1.21 .{ }^{1} \mathrm{H}$ NMR (600 MHz, $\mathrm{CDCl}_{3}, 25^{\circ} \mathrm{C}$ ): $\delta 7.33$ (brs, 2H, aromatic), 5.75 (brs, 2H, aromatic), 4.04-3.76 (brs, 
2H, $\left.\mathrm{OCH}_{2}\right), 1.25-0.84$ (brs, $19 \mathrm{H}, \mathrm{CH}_{2}$ and $\left.\mathrm{CH}_{3}\right)$. FT-IR $\left(\mathrm{KBr}, \mathrm{cm}^{-1}\right): 2960\left(v_{\mathrm{C}-\mathrm{H}}\right), 2930\left(v_{\mathrm{C}-\mathrm{H}}\right), 2860$ $(v \mathrm{C}-\mathrm{H}), 1720\left(v_{\mathrm{C}=\mathrm{O}}\right), 1630\left(v_{\mathrm{C}=\mathrm{N}}\right), 1100\left(v_{\mathrm{Si}-\mathrm{O}}\right), 465\left(v_{\mathrm{Si}-\mathrm{O}}\right)$.

Synthesis of poly-2L $100-\mathrm{SiO}_{2}$ : This chiral hybrid nanoparticle was prepared in $90 \%$ yield followed the same procedure to that of poly-1 ${ }_{100}-\mathrm{SiO}_{2}$ by using poly-2L100-TEOS. SEC: $M_{\mathrm{n}}=4.92 \times 10^{4}, M_{\mathrm{w}} / M_{\mathrm{n}}$ $=1.16 .{ }^{1} \mathrm{H} \mathrm{NMR}\left(600 \mathrm{MHz}, \mathrm{CDCl}_{3}, 25^{\circ} \mathrm{C}\right): \delta 8.83-7.65$ (brs, $\left.1 \mathrm{H}, \mathrm{NH}\right), 6.86-5.42$ (brs, $4 \mathrm{H}$, aromatic), 4.51 (brs, $\mathrm{H}, \mathrm{CH}$ ), 4.09 (brs, 2H, $\mathrm{CH}_{2}$ ), 1.55-1.24 (brs, 19H, $\mathrm{CH}_{2}$ and $\mathrm{CH}_{3}$ ), 0.87 (brs, 3H, $\mathrm{CH}_{3}$ ). FTIR $\left(\mathrm{KBr}, \mathrm{cm}^{-1}\right): 2960\left(v_{\mathrm{C}-\mathrm{H}}\right), 2930\left(v_{\mathrm{C}-\mathrm{H}}\right), 2860\left(v_{\mathrm{C}-\mathrm{H}}\right), 1720\left(v_{\mathrm{C}=\mathrm{O}}\right), 1630\left(v_{\mathrm{C}=\mathrm{N}}\right), 1100\left(v_{\mathrm{Si}-\mathrm{O}}\right), 465\left(v_{\mathrm{Si}-}\right.$ o).

Typical Procedure for Enantioselective Crystallization: The crystallization experiments were carried out on a supersaturated solution of racemic Boc-alanine in methanol. Racemic Boc-alanine (3.00 g) were added to methanol $(10 \mathrm{~mL})$, and the solution was heated to $35^{\circ} \mathrm{C}$ under stirring for complete dissolution. Approximately $10.0 \mathrm{mg}$ of poly-2 $\mathrm{L}_{100}-\mathrm{SiO}_{2}$ was placed into the supersaturated solution and stirred/sonicated for about $30 \mathrm{~min}$. The dispersion was left for ambient cooling till room temperature (approximately $25^{\circ} \mathrm{C}$ ). The formed crystal was filtrated, washed with cold methanol, and dried under vacuum at room temperature to afford optical active Boc- $D$-alanine. The e.e. values were determined via the comparison of molar CD intensity at $210 \mathrm{~nm}$ of the induced crystal with the commercial enantiopure Boc- $D$-alanine or Boc- $L$-alanine, and were further confirmed by the date of optical rotation $\left(c=0.15\right.$, methanol, $\left.25^{\circ} \mathrm{C}\right)$.

\section{References}

(1) (a) Xue, Y.-X.; Zhu, Y.-Y.; Gao, L.-M.; He, X.-Y.; Liu, N.; Zhang, W.-Y.; Yin, J.; Ding, Y.; Zhou, H.; Wu, Z.-Q. Air-Stable (Phenylbuta-1,3-diynyl)palladium(II) Complexes: Highly Active Initiators for Living Polymerization of Isocyanides. J. Am. Chem. Soc. 2014, 136, 4706. (b) Xue, Y.-X.; Chen, 
J.-L.; Jiang, Z.-Q.; Yu, Z.-P.; Liu, N.; Yin, J.; Zhu, Y.-Y.; Wu, Z.-Q. Living polymerization of arylisocyanide initiated by the phenylethynyl palladium(II) complex. Polym. Chem. 2014, 5, 6435. (c) Chen, J.-L.; Su, M.; Jiang, Z.-Q.; Liu, N.; Yin, J.; Zhu, Y.-Y.; Wu, Z.-Q. Facile synthesis of stereoregular helical poly(phenyl isocyanide)s and poly(phenyl isocyanide)-block-poly(L-lactic acid) copolymers using alkylethynylpalladium(II) complexes as initiators. Polym. Chem. 2015, 6, 4784.

(2) Lu, X.-Y.; Sun, F.; Wang, J.; Zhong, J.-F.; Dong, Q.-Z. A Facile Route to Prepare Organic/Inorganic Hybrid Nanomaterials by “Click Chemistry”. Macromol. Rapid Commun. 2009, 30, 2116.

(3) (a) Stöber, W.; Fink, A.; Bohn, E. J. Controlled growth of monodisperse silica spheres in the micron size range. Colloid Interface Sci. 1968, 26, 62. (b) Li, D.; Sheng, X.; Zhao, B. Environmentally Responsive "Hairy" Nanoparticles: Mixed Homopolymer Brushes on Silica Nanoparticles Synthesized by Living Radical Polymerization Techniques. J. Am. Chem. Soc. 2005, 127, 6248.

(4) (a) Li, D.; Sheng, X.; Zhao, B. Environmentally Responsive "Hairy" Nanoparticles: Mixed Homopolymer Brushes on Silica Nanoparticles Synthesized by Living Radical Polymerization Techniques. J. Am. Chem. Soc. 2005, 127, 6248. (b) Kang, S.-S.; Ono, R. J.; Bielawski, C. W. Controlled Catalyst Transfer Polycondensation and Surface-Initiated Polymerization of a pPhenyleneethynylene-Based Monomer. J. Am. Chem. Soc. 2013, 135, 4984. 
Table S1. $M_{\mathrm{n}}$ and $M_{\mathrm{w}} / M_{\mathrm{n}}$ Date of Poly-1 $\mathbf{1}_{\mathrm{m}}$ Arms Etched Form the Corresponding Poly-1 $\mathbf{m}_{\mathrm{m}-\mathrm{SiO}} \mathrm{Hybrid}$ Silica Nanoparticles ${ }^{a}$

\begin{tabular}{ccccc}
\hline run & $\left.[\mathbf{1}]_{0} / \mathrm{Pd}\right]_{0}{ }^{b}$ & poly-1 & $M_{\mathrm{m}}{ }^{c}(\mathrm{Da})$ & $M_{w} / M_{n}{ }^{c}$ \\
\hline 1 & 20 & poly-1 & $5.5 \times 10^{3}$ & 1.13 \\
2 & 40 & poly-1 & $8.6 \times 10^{3}$ & 1.17 \\
3 & 60 & poly-1 & $1.35 \times 10^{4}$ & 1.19 \\
4 & 80 & poly-1 $_{80}$ & $1.98 \times 10^{4}$ & 1.18 \\
5 & 100 & poly-1 $_{100}$ & $2.58 \times 10^{4}$ & 1.19 \\
6 & 120 & poly-1 $_{120}$ & $2.95 \times 10^{4}$ & 1.20 \\
\hline
\end{tabular}

${ }^{a}$ The poly-1 $\mathbf{m}_{\mathrm{m}}$ arms were etched from the corresponding hybrid silica nanoparticles grafted with poly$1 \mathrm{~m}$ using HF at room temperature in THF. ${ }^{b}$ The initial feed ratio of monomer $\mathbf{1}$ to the $\mathrm{Pd}$ (II) units anchored on the surface of silica nanoparticle. ${ }^{c}$ The $M_{\mathrm{n}}$ and $M_{\mathrm{w}} / M_{\mathrm{n}}$ data were estimated by SEC analyses with equivalent to polystyrene standard.

Table S2. Results for the Synthesis of Hybrid Silica Nanoparticle Poly- $\mathbf{1}_{\mathrm{m}}-\mathrm{SiO}_{2}$ via "Grafting to" Strategy

\begin{tabular}{cccccccc}
\hline run & poly-1 $_{\mathrm{m}}{ }^{a}$ & $M_{\mathrm{n}}(\mathrm{Da})^{b}$ & $M_{\mathrm{w}} / M_{\mathrm{n}}{ }^{b}$ & poly-1 $_{\mathrm{m}}-\mathrm{SiO}_{2}{ }^{a}$ & $M_{\mathrm{n}}(\mathrm{Da})^{b}$ & $M_{\mathrm{w}} / M_{\mathrm{n}}{ }^{b}$ & $\mathrm{Yield}^{c}$ \\
\hline 1 & poly-1 $_{20}$ & $6.5 \times 10^{3}$ & 1.12 & poly-1$_{20}-\mathrm{SiO}_{2}$ & $1.77 \times 10^{4}$ & 1.22 & $71 \%$ \\
2 & poly-1 $_{40}$ & $1.16 \times 10^{4}$ & 1.14 & poly-1 $_{40}-\mathrm{SiO}_{2}$ & $2.16 \times 10^{4}$ & 1.21 & $72 \%$ \\
3 & poly-1 $_{60}$ & $1.55 \times 10^{4}$ & 1.12 & poly-1 $_{60}-\mathrm{SiO}_{2}$ & $2.65 \times 10^{4}$ & 1.19 & $75 \%$ \\
4 & poly-1 $_{100}$ & $2.80 \times 10^{4}$ & 1.16 & poly-1 $_{100}-\mathrm{SiO}_{2}$ & $3.95 \times 10^{4}$ & 1.21 & $76 \%$ \\
\hline
\end{tabular}

${ }^{a}$ The poly-1 $\mathrm{m}$ and poly-1 $\mathbf{1}_{\mathrm{m}}-\mathrm{SiO}_{2}$ were synthesized according to Scheme 2 in the main text. ${ }^{b} \mathrm{The} M_{\mathrm{n}}$ and $M_{\mathrm{w}} / M_{\mathrm{n}}$ data were estimated by SEC with equivalent to polystyrene standard. ${ }^{c}$ Isolated yields. 


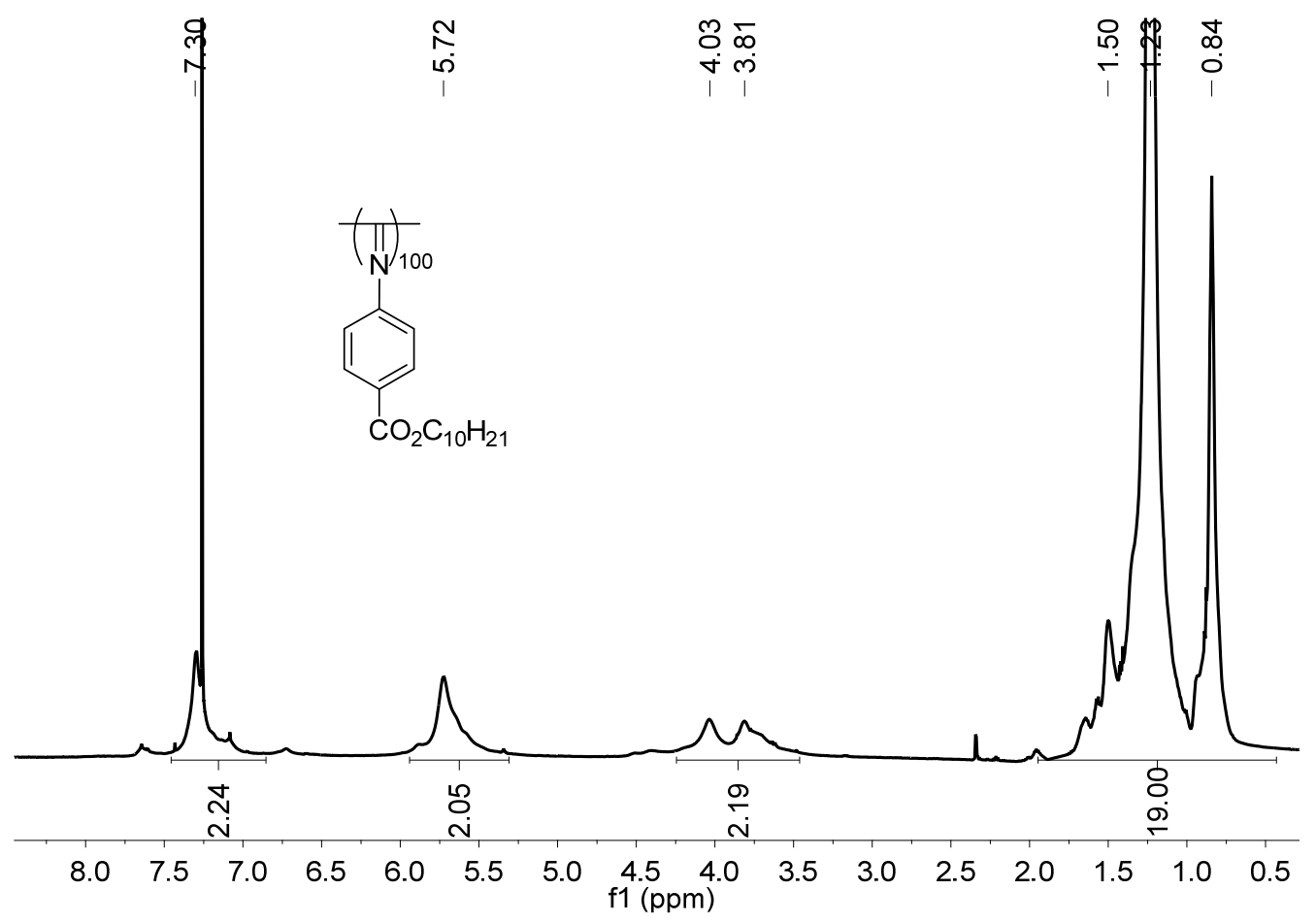

Figure S1. ${ }^{1} \mathrm{H}$ NMR spectrum of poly-1 100 arm etched from $\mathrm{SiO}_{2}$-poly-1 $\mathbf{1}_{100}$ hybrid nanoparticle measured in $\mathrm{CDCl}_{3}$ at $25^{\circ} \mathrm{C}(600 \mathrm{MHz})$.

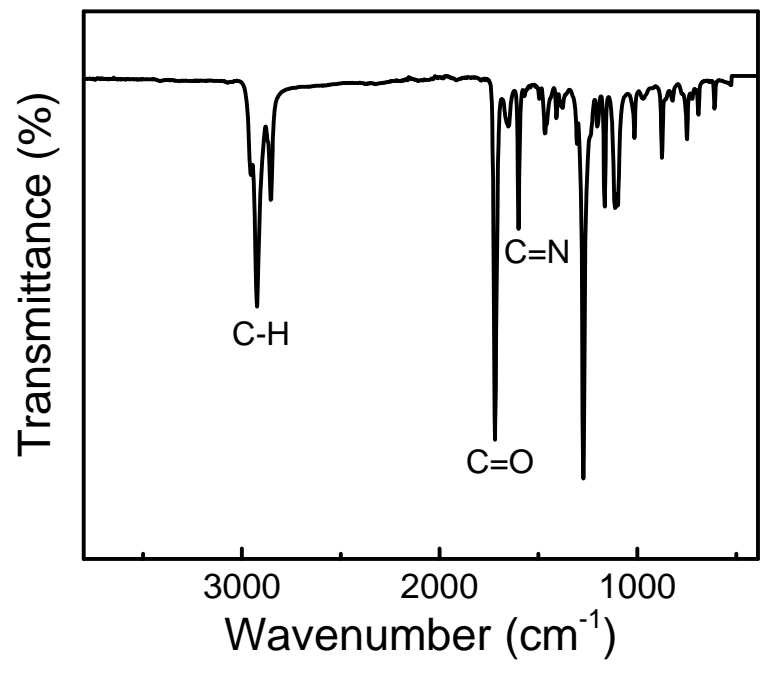

Figure S2. FT-IR spectrum of poly-1 100 arm etched from $\mathrm{SiO}_{2}-$ poly-1 100 hybrid nanoparticle measured at $25{ }^{\circ} \mathrm{C}$ using $\mathrm{KBr}$ pellet. 

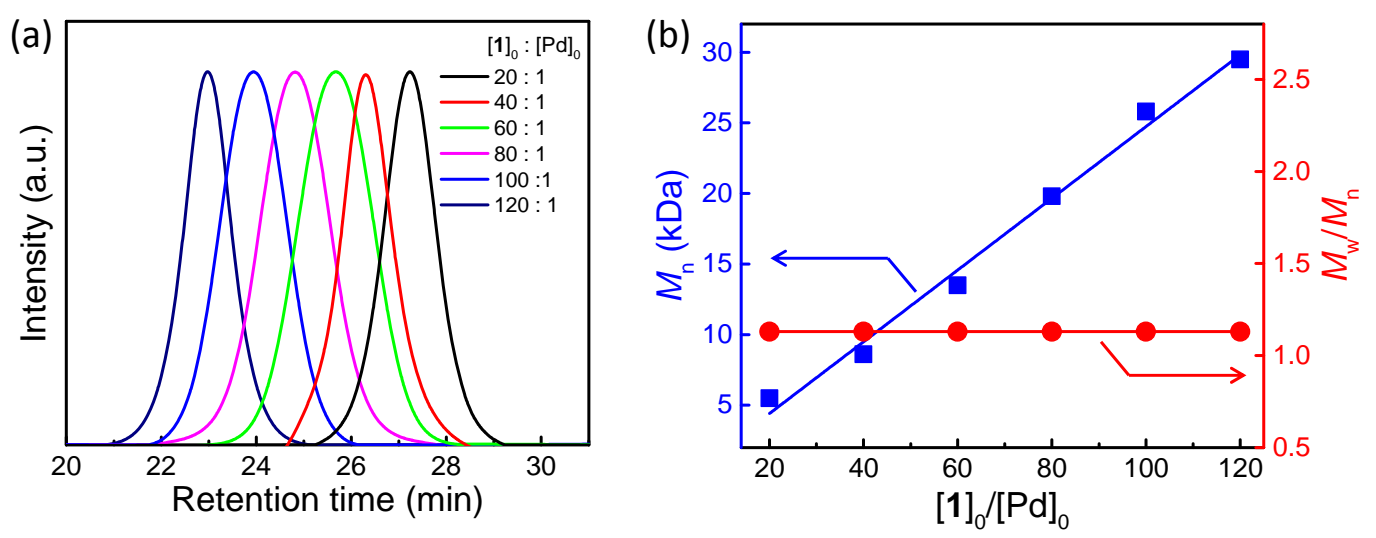

Figure S3. (a) Size exclusion chromatograms of poly-1 $\mathbf{1}_{\mathrm{m}}$ arms etched from the $\mathrm{SiO}_{2}$-poly-1 $\mathbf{1}_{\mathrm{m}}$ hybrid nanoparticles prepared via the surface-initiated polymerization of $\mathbf{1}$ using different initial feed of monomer to initiator. (b) Plots of $M_{\mathrm{n}}$ and $M_{\mathrm{w}} / M_{\mathrm{n}}$ values of poly-1 $\mathrm{m}$ arms etched from the $\mathrm{SiO}_{2}-$ poly-1 $\mathbf{1}_{\mathrm{m}}$ hybrid nanoparticles with the initial feed ratios of monomer to initiator of the surface-initiated polymerization of monomer 1 in $\mathrm{THF}$ at $55^{\circ} \mathrm{C}$.

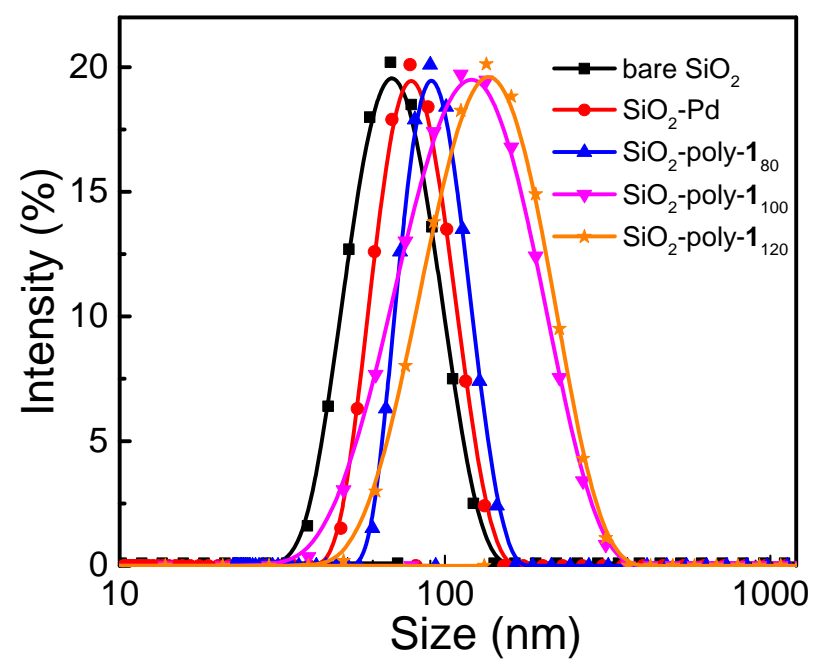

Figure S4. DLS curves of bare silica nanoparticle and the resulting $\mathrm{SiO}_{2}$-poly-1 $\mathbf{1}_{\mathrm{mS}}$ hybrid silica nanoparticles grafted with poly-1 $\mathrm{m}$ arms with different chain length measured in THF at $25^{\circ} \mathrm{C}$. 


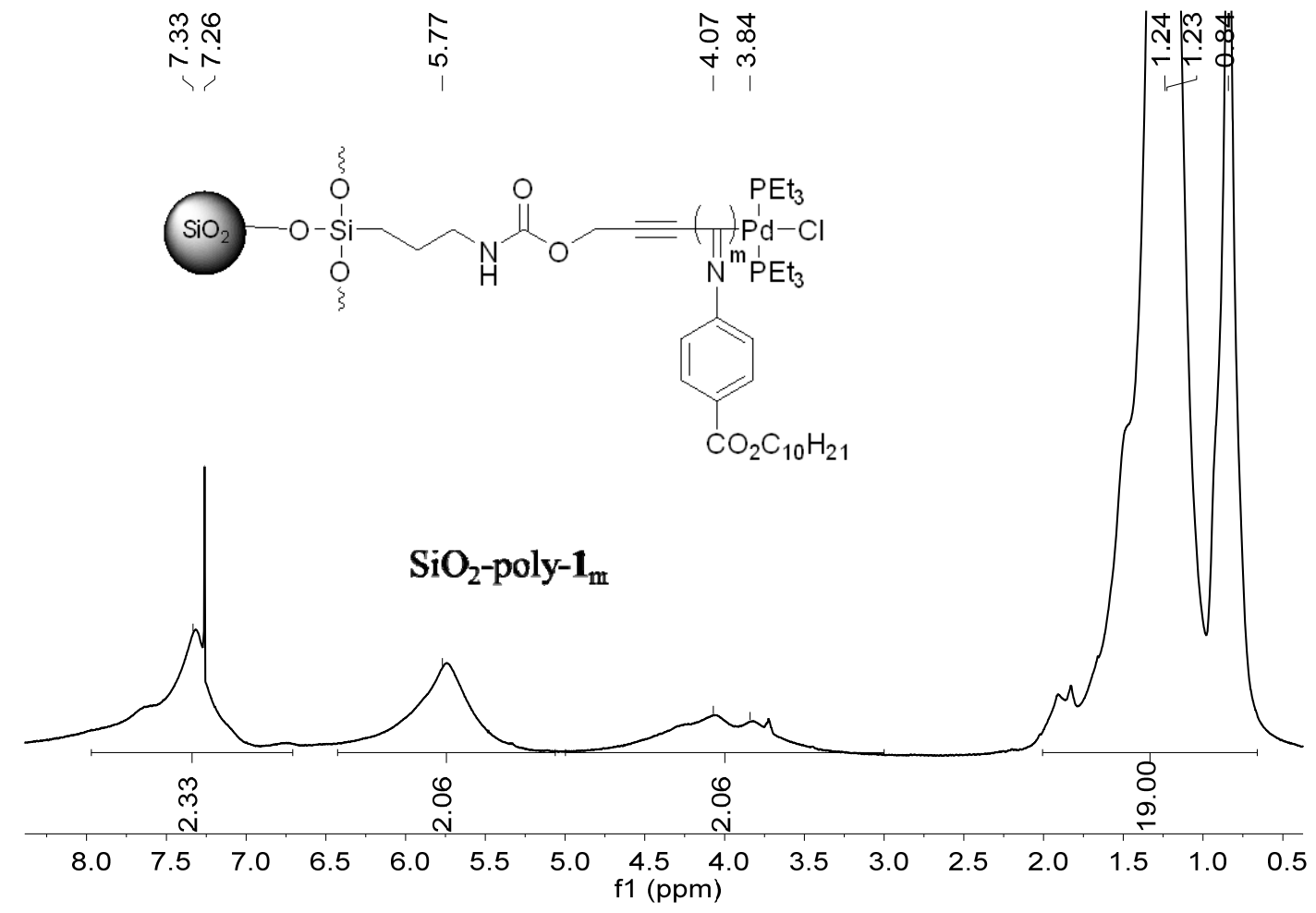

Figure S5. ${ }^{1} \mathrm{H}$ NMR spectrum of $\mathrm{SiO}_{2}$-poly-1 100 measured in $\mathrm{CDCl}_{3}$ at $25{ }^{\circ} \mathrm{C}(600 \mathrm{MHz})$.

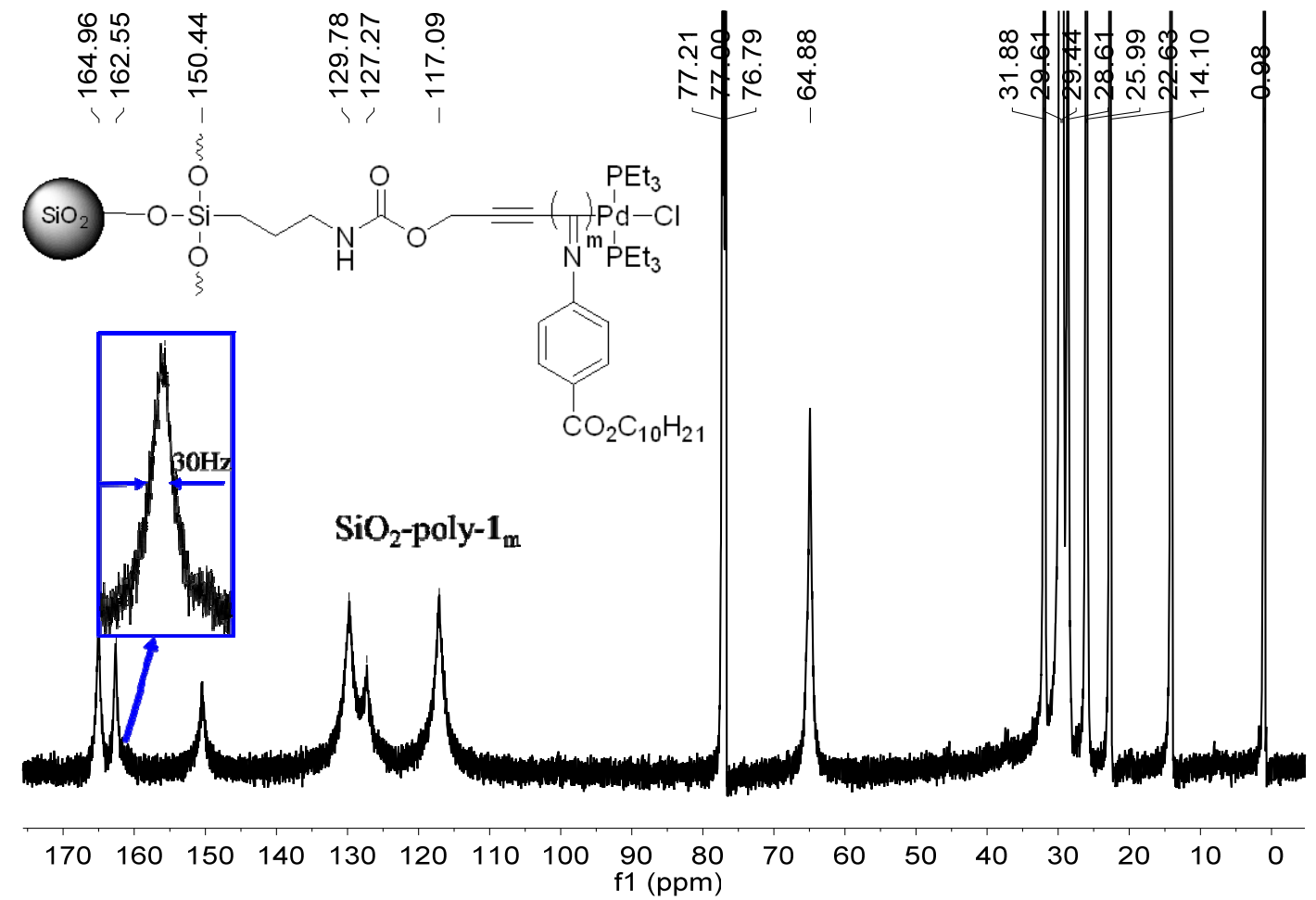

Figure S6. ${ }^{13} \mathrm{C}$ NMR spectrum of $\mathrm{SiO}_{2}$-poly-1 $\mathbf{1}_{100}$ measured in $\mathrm{CDCl}_{3}$ at $25{ }^{\circ} \mathrm{C}(150 \mathrm{MHz})$. 


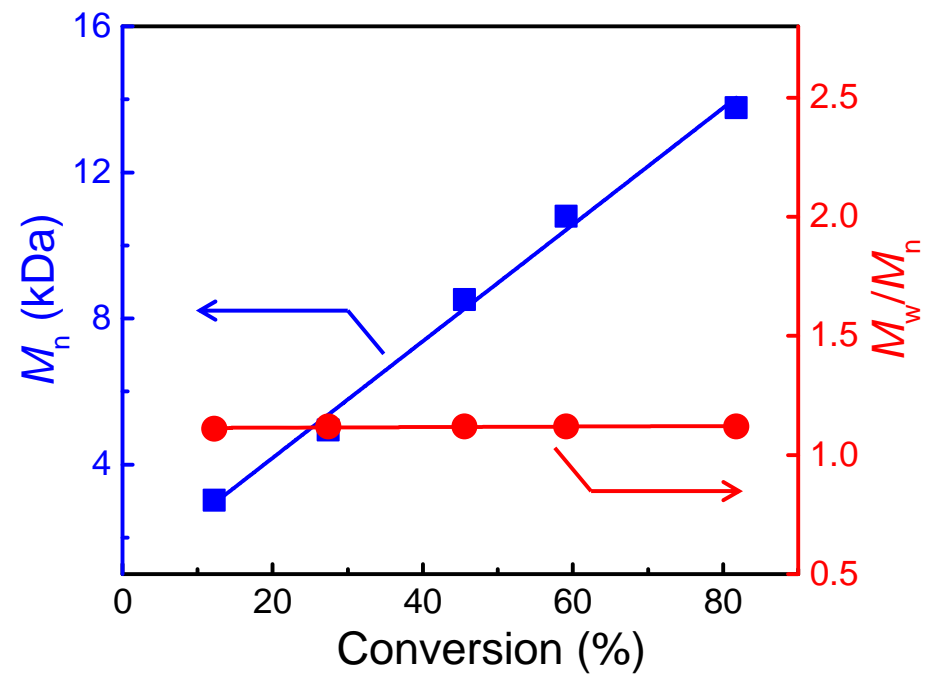

Figure S7. Plots of $M_{\mathrm{n}}$ and $M_{\mathrm{w}} / M_{\mathrm{n}}$ values of the poly-1 $\mathbf{1}_{\mathrm{m}}$ arms etched from the $\mathrm{SiO}_{2}-$ poly-1 $\mathbf{1}_{\mathrm{m}}$ hybrid silica nanoparticles isolated at different polymerization stage of the surface-initiated polymerization of monomer 1 in $\mathrm{THF}$ at $55^{\circ} \mathrm{C}\left([\mathbf{1}]_{0}=0.2 \mathrm{M},[\mathbf{1}]_{0} /[\mathrm{Pd}]_{0}=100\right)$.

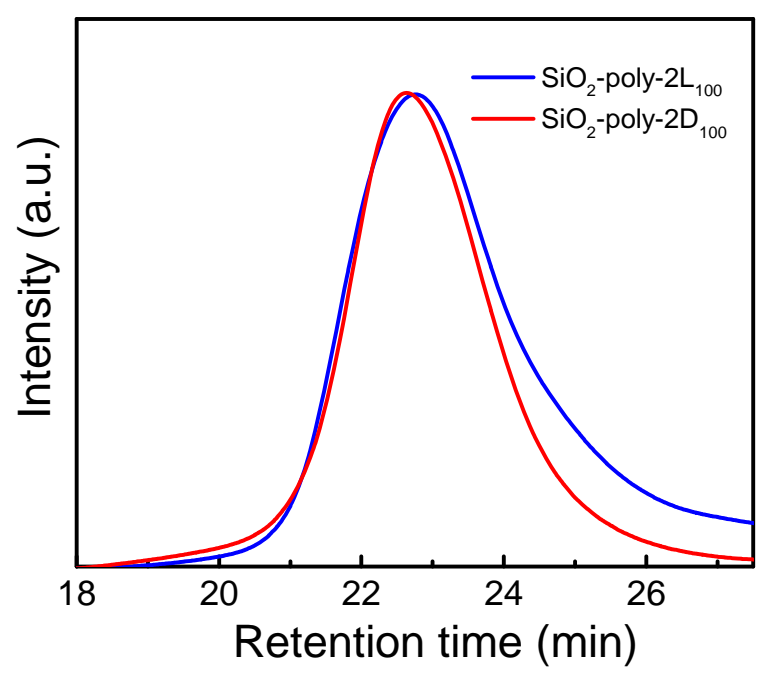

Figure S8. SEC curves for chiral hybrid silica nanoparticles $\mathrm{SiO}_{2}-$ poly-2L100 and $\mathrm{SiO}_{2}-$ poly-2D100. SEC conditions: eluent $=\mathrm{THF}$, temperature $=40^{\circ} \mathrm{C}$. 


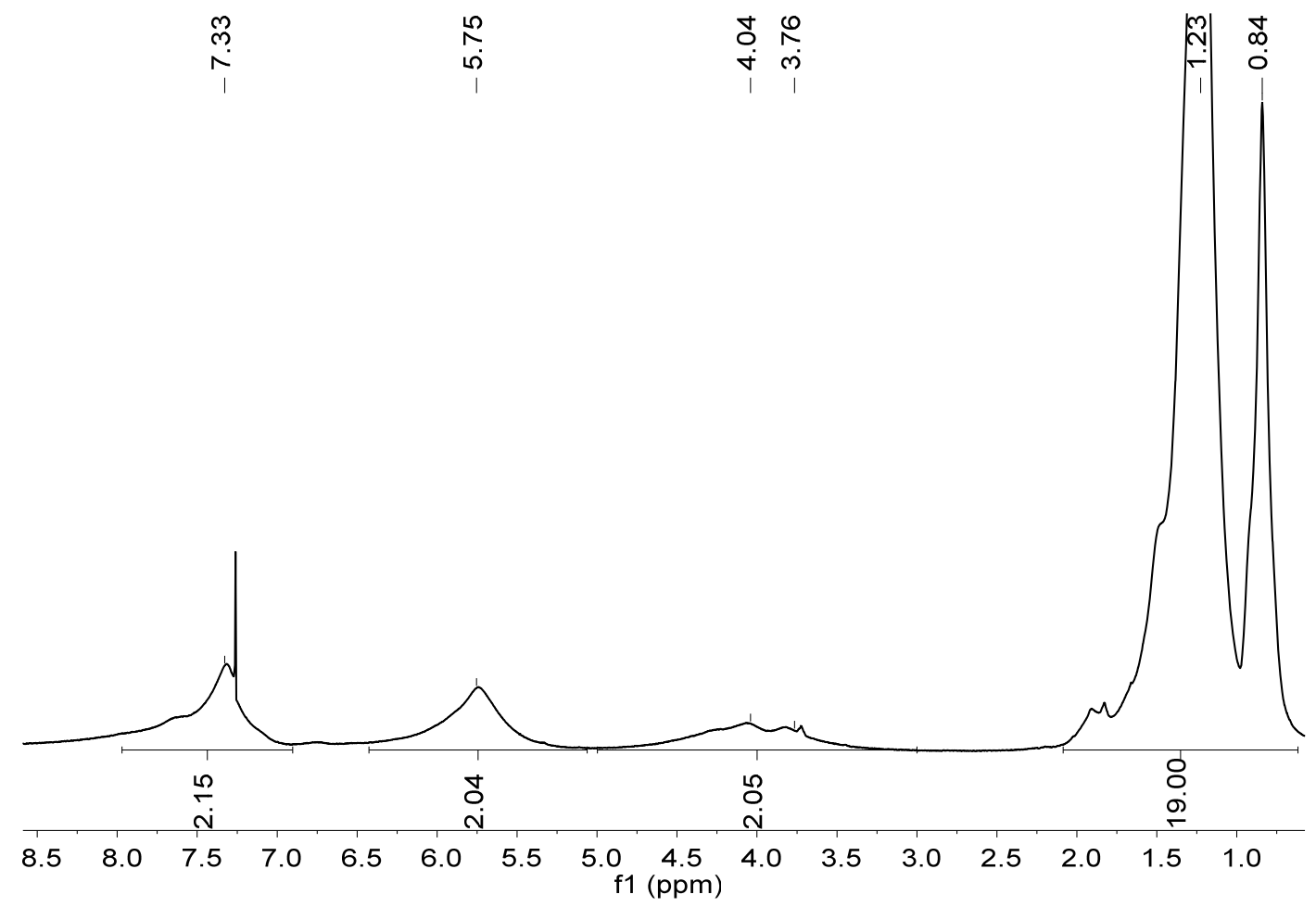

Figure S9. ${ }^{1} \mathrm{H}$ NMR spectrum of poly-1 $1_{100}-\mathrm{SiO}_{2}$ measured in $\mathrm{CDCl}_{3}$ at $25{ }^{\circ} \mathrm{C}(600 \mathrm{MHz})$.

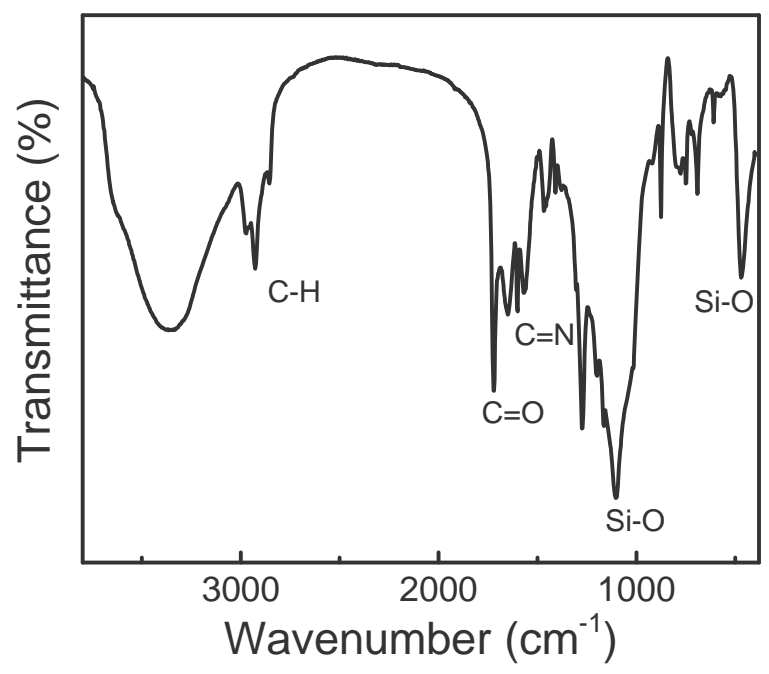

Figure S10. FT-IR spectrum of hybrid silica nanoparticle poly-1 ${ }_{100}-\mathrm{SiO}_{2}$ prepared via "grafting to" strategy measured at $25^{\circ} \mathrm{C}$ using $\mathrm{KBr}$ pellet. 


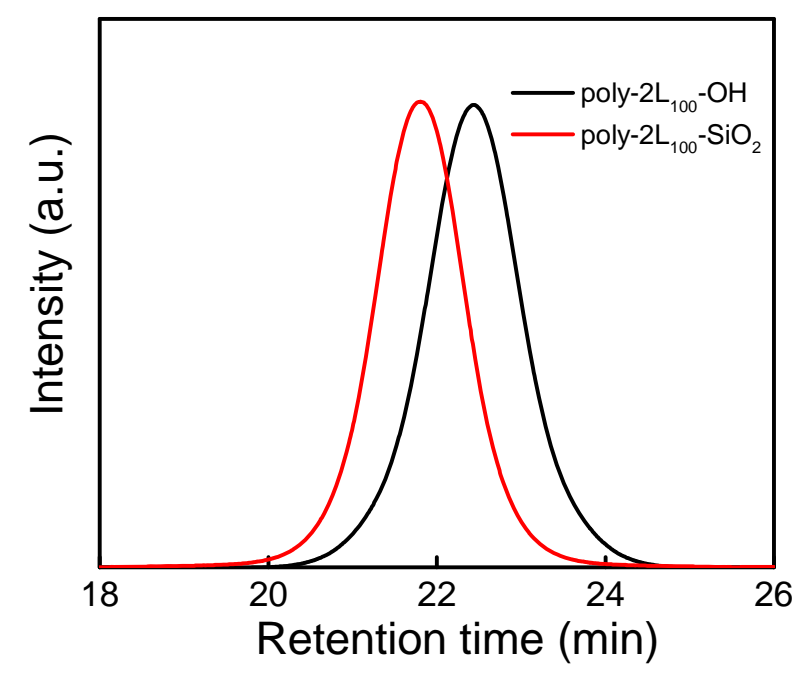

Figure S11. SEC curves of the optically active helical poly(phenyl isocyanide) poly-2L $100-\mathrm{OH}$ and the resulting chiral hybrid silica nanoparticle poly-2L $100-\mathrm{SiO}_{2}$ prepared via "grafting to" strategy. SEC conditions: eluent $=\mathrm{THF}$, temperature $=40^{\circ} \mathrm{C}$.

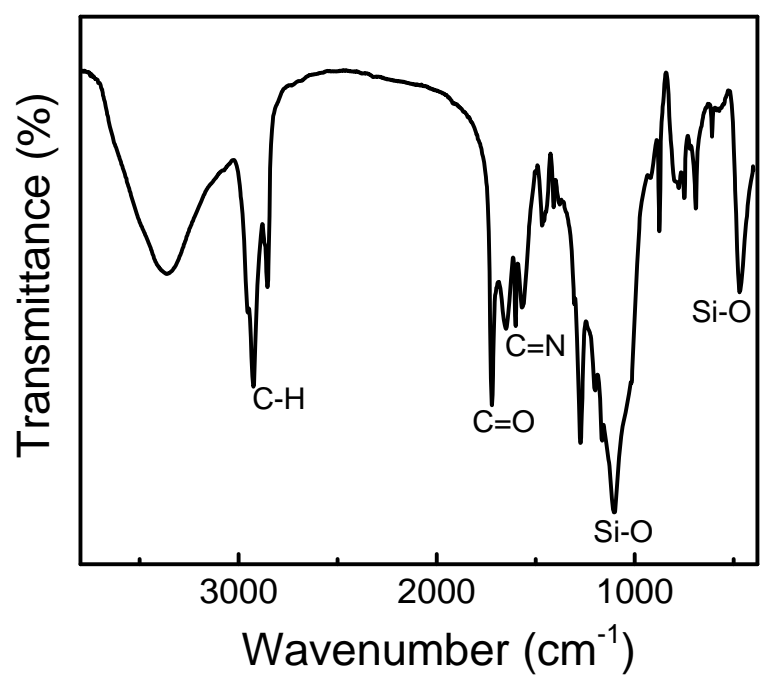

Figure S12. FT-IR spectrum of the chiral hybrid silica nanoparticle poly-2L $100-\mathrm{SiO}_{2}$ grafted with lefthanded helical poly-2L100 arms prepared via "grafting to" strategy measured at $25^{\circ} \mathrm{C}$ using $\mathrm{KBr}$ pellet. 


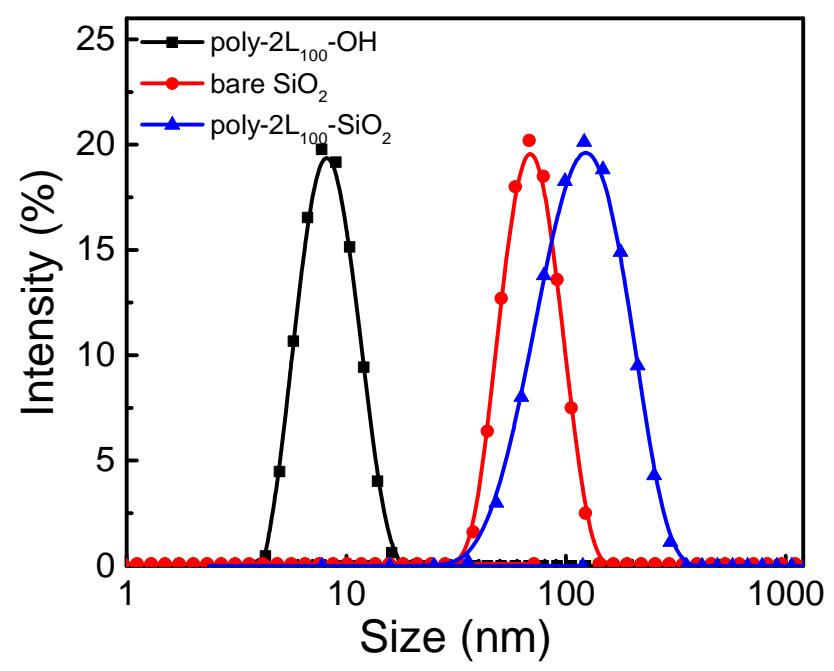

Figure S13. DLS curves for left-handed helical poly(phenyl isocyanide) poly-2L $100-\mathrm{OH}$ and the resulting chiral hybrid silica nanoparticle poly-2L $100-\mathrm{SiO}_{2}$ grafted with left-handed poly-2L100 arms measured in THF at $25^{\circ} \mathrm{C}$.

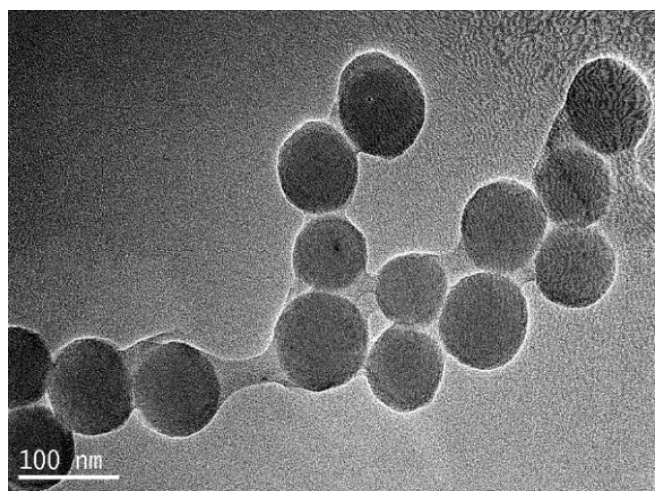

Figure S14. TEM image of the chiral hybrid silica nanoparticle poly-2 $\mathrm{L}_{100}-\mathrm{SiO}_{2}$ grafted with lefthanded helical poly-2L100 arms. 


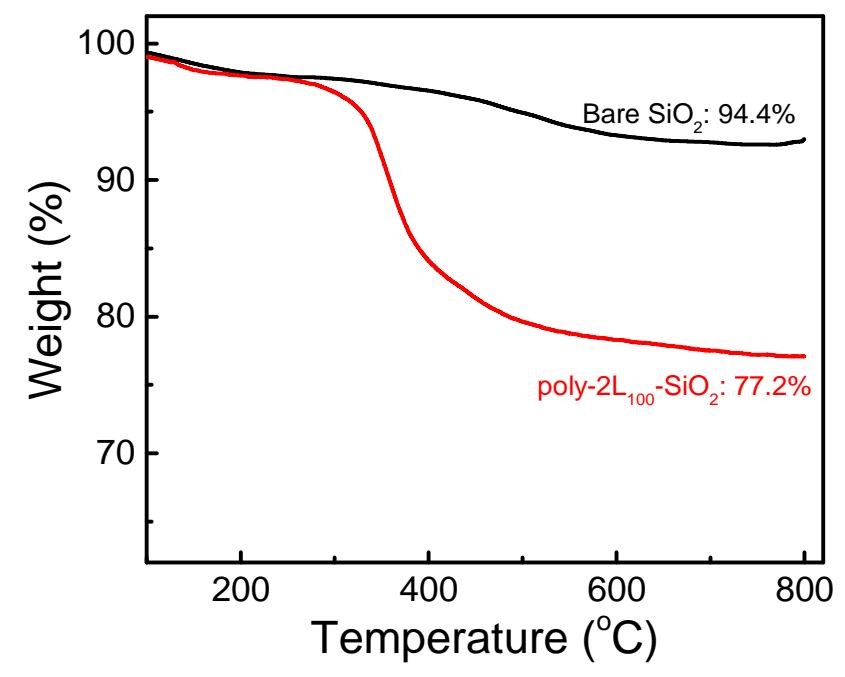

Figure S15. TGA curves for bare silica nanoparticle and the resulting poly-2L $100-\mathrm{SiO}_{2}$ hybrid silica nanoparticle grafted with left-handed helical poly-2L100 arms. TGA was performed in air at a heating rate of $10^{\circ} \mathrm{C} / \mathrm{min}$.

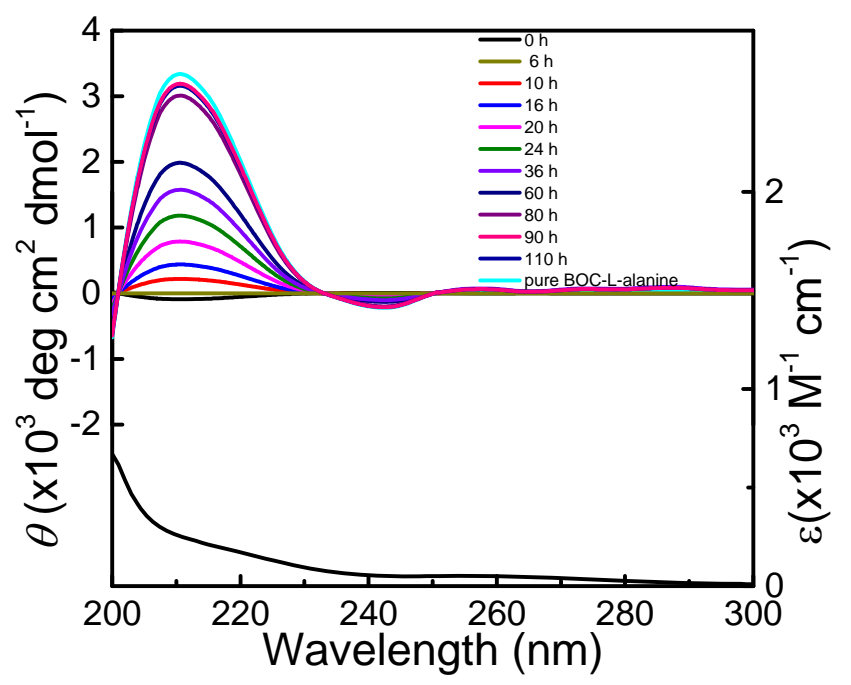

Figure S16. Time-dependent CD and UV-vis absorption spectra of the solution of enantioselective crystallization of racemic Boc-alanine in methanol induced by chiral poly-2 $\mathrm{L}_{100}-\mathrm{SiO}_{2}$ at room temperature. 


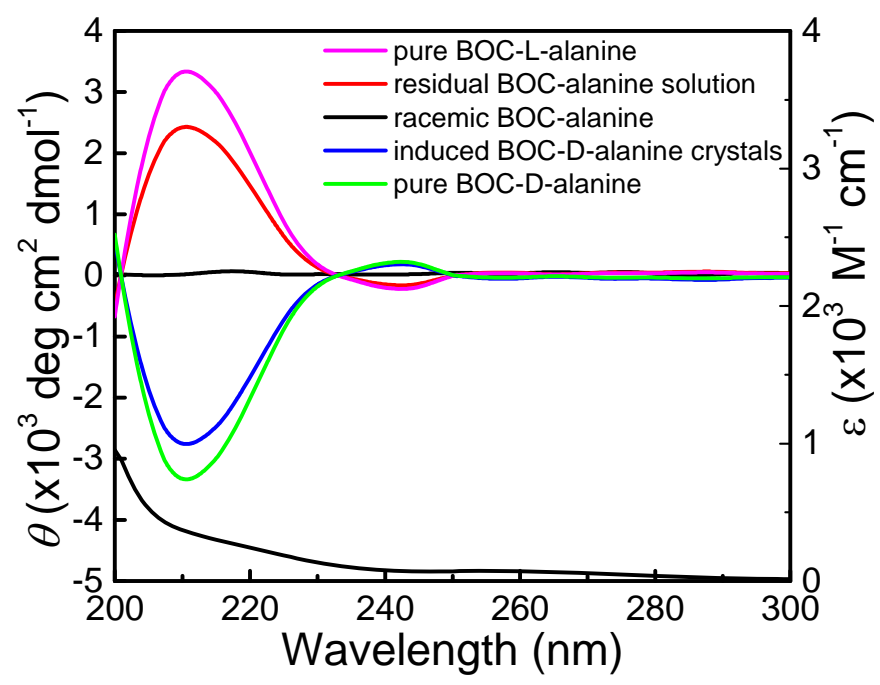

Figure S17. CD and UV-vis spectra of enantioselective crystallization in racemic Boc-alanine solution induced by chiral $\mathrm{SiO}_{2}$-poly-2L100 measured in methanol at room temperature.

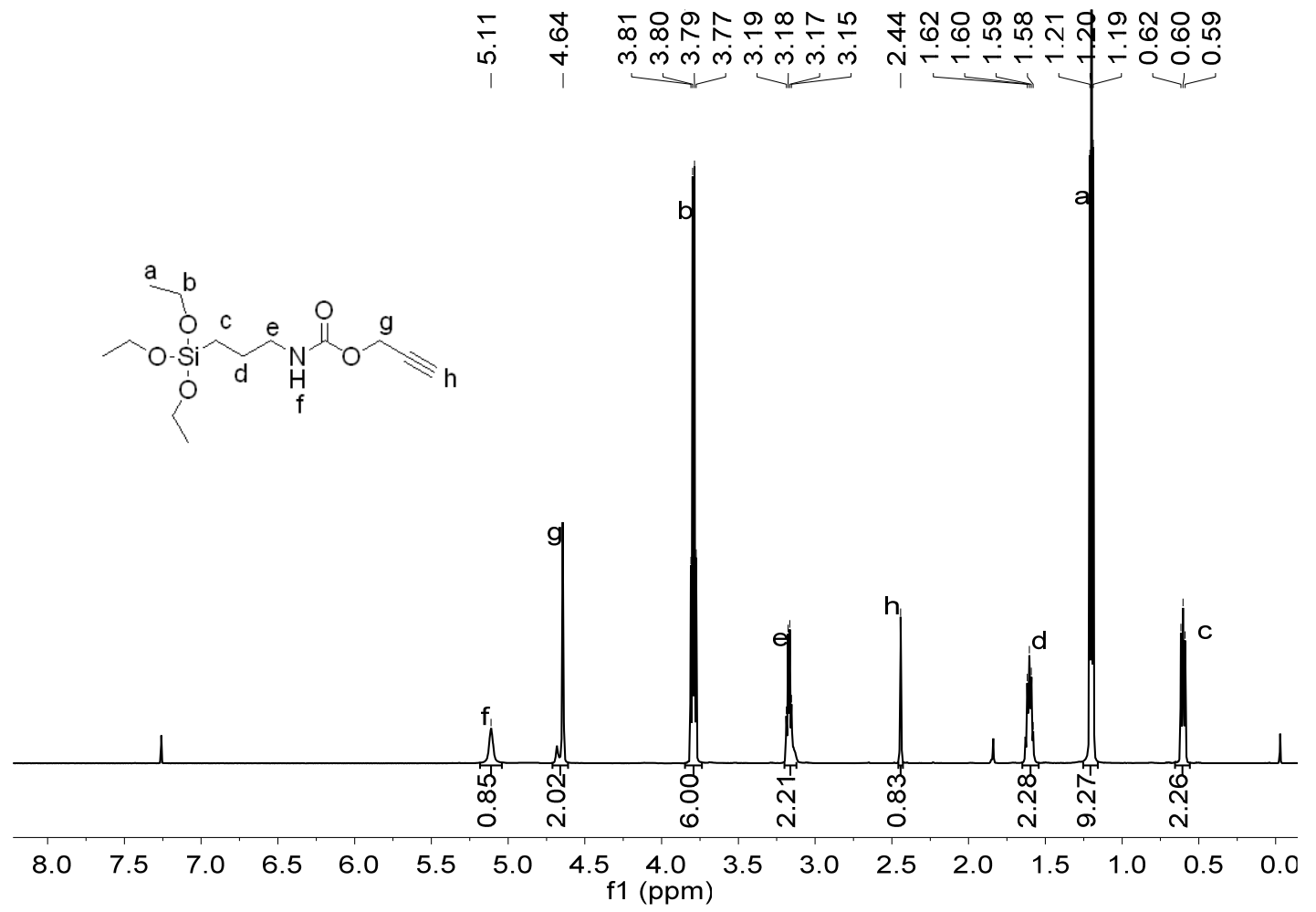

Figure S18. ${ }^{1} \mathrm{H}$ NMR spectrum of 3 measured in $\mathrm{CDCl}_{3}$ at $25^{\circ} \mathrm{C}(600 \mathrm{MHz})$. 


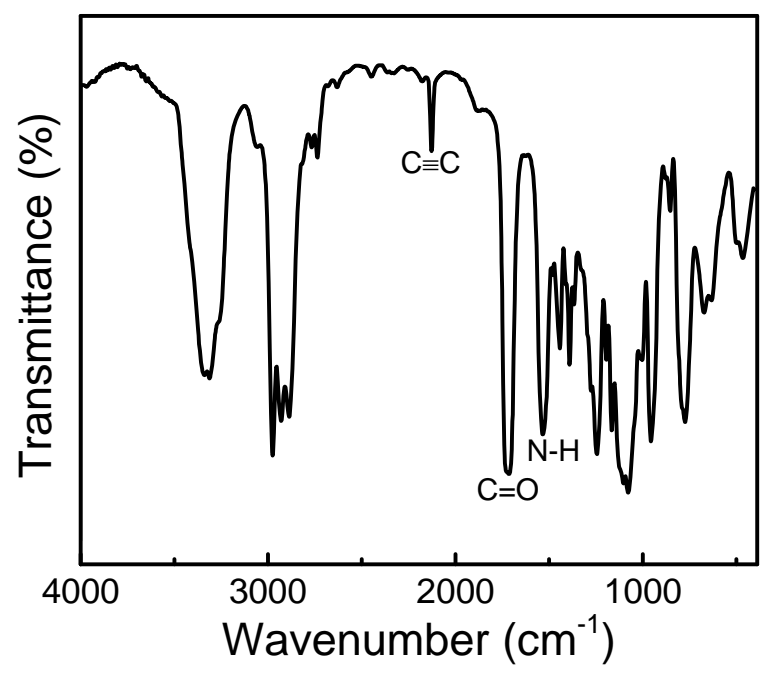

Figure S19. FT-IR spectrum of 3 measured at $25^{\circ} \mathrm{C}$ using $\mathrm{KBr}$ pellet.

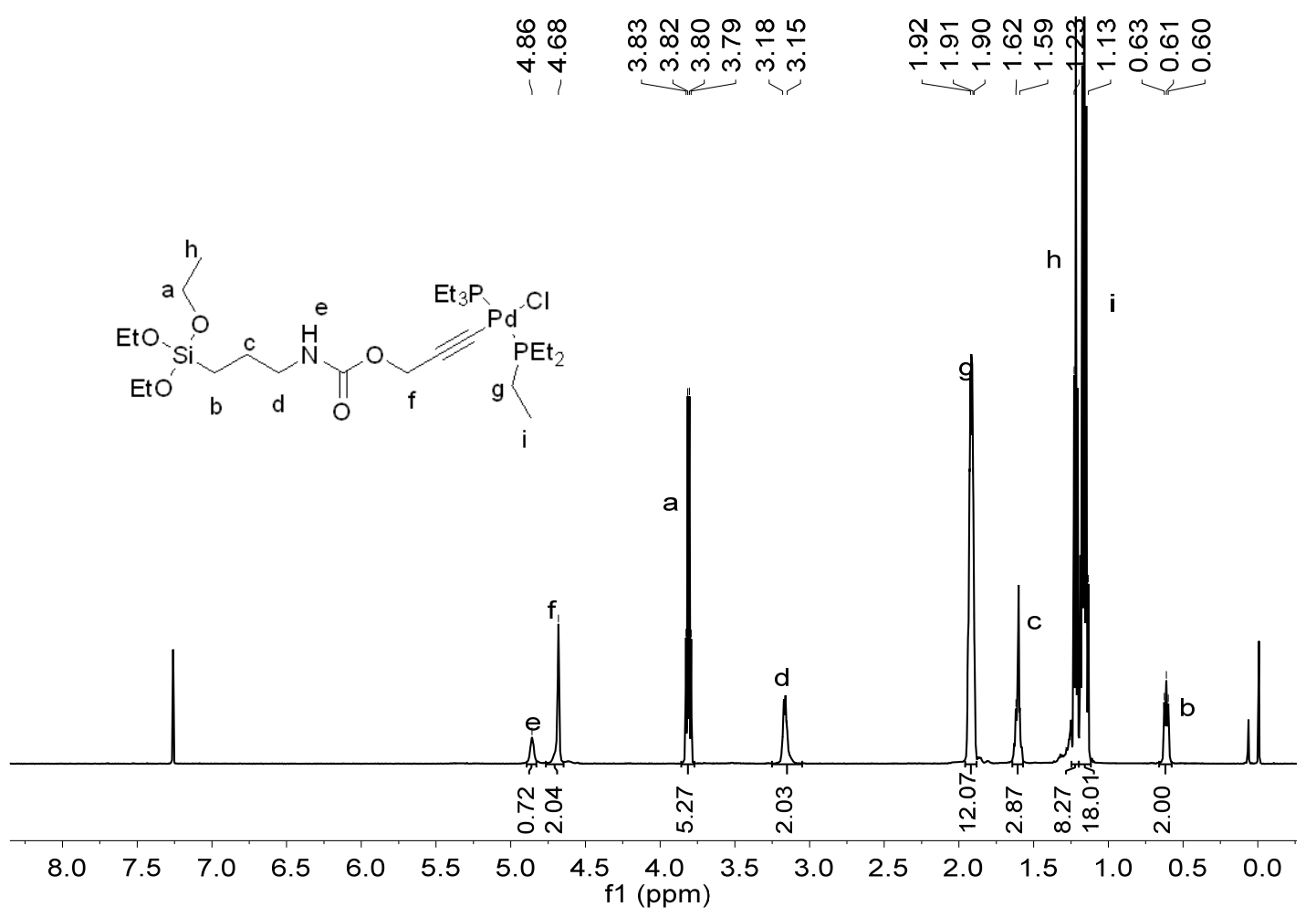

Figure S20. ${ }^{1} \mathrm{H}$ NMR spectrum of TEOS-Pd(II) measured in $\mathrm{CDCl}_{3}$ at $25{ }^{\circ} \mathrm{C}(600 \mathrm{MHz})$. 


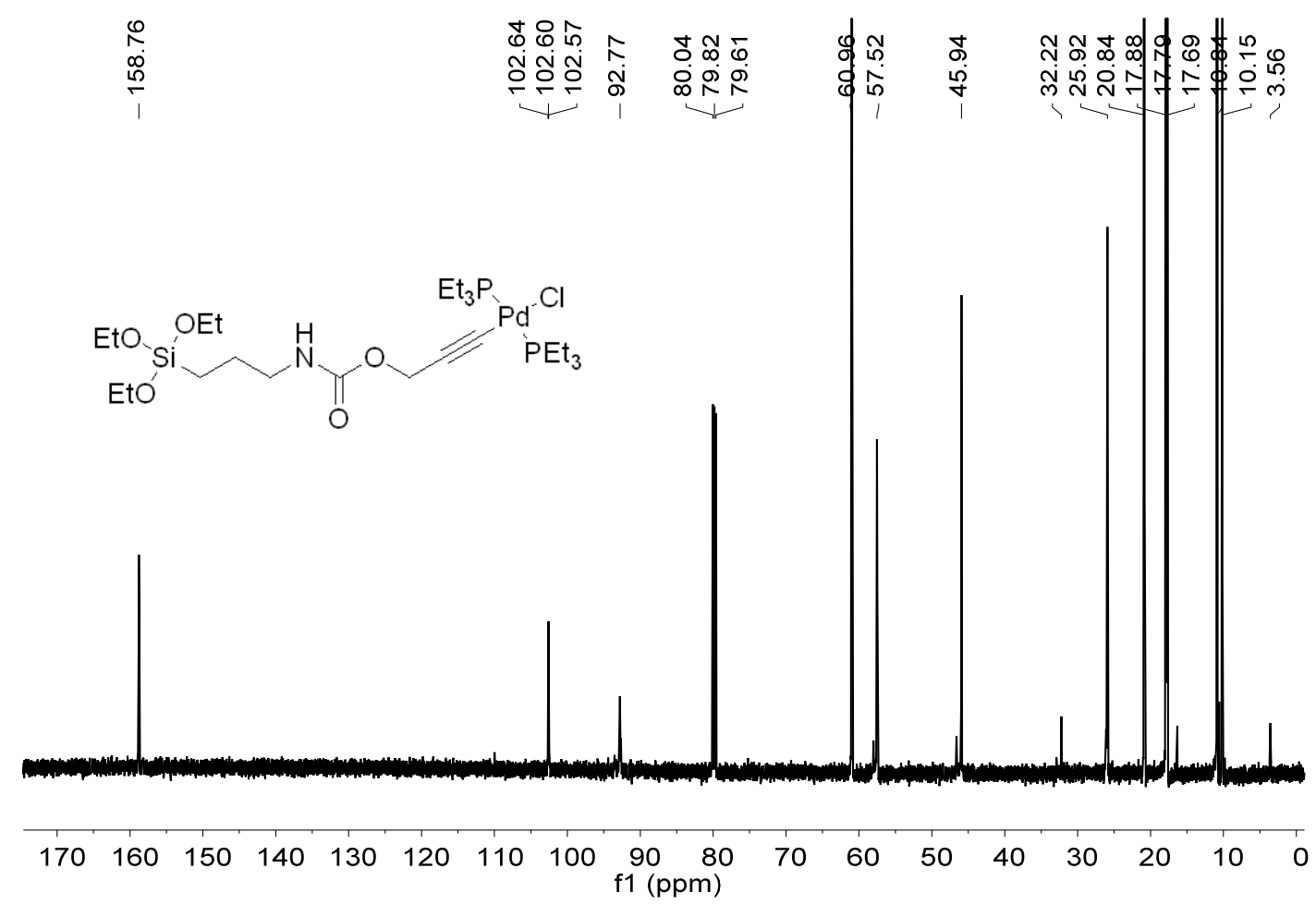

Figure S21. ${ }^{13} \mathrm{C}$ NMR spectrum of TEOS-Pd(II) measured in $\mathrm{CDCl}_{3}$ at $25{ }^{\circ} \mathrm{C}(150 \mathrm{MHz})$.

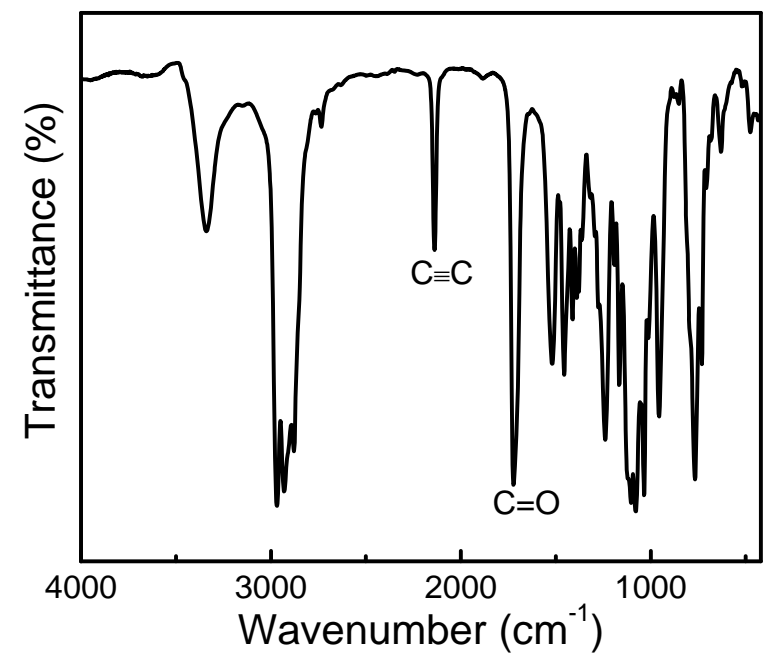

Figure S22. FT-IR spectrum of TEOS-Pd(II) measured at $25^{\circ} \mathrm{C}$ using $\mathrm{KBr}$ pellet. 


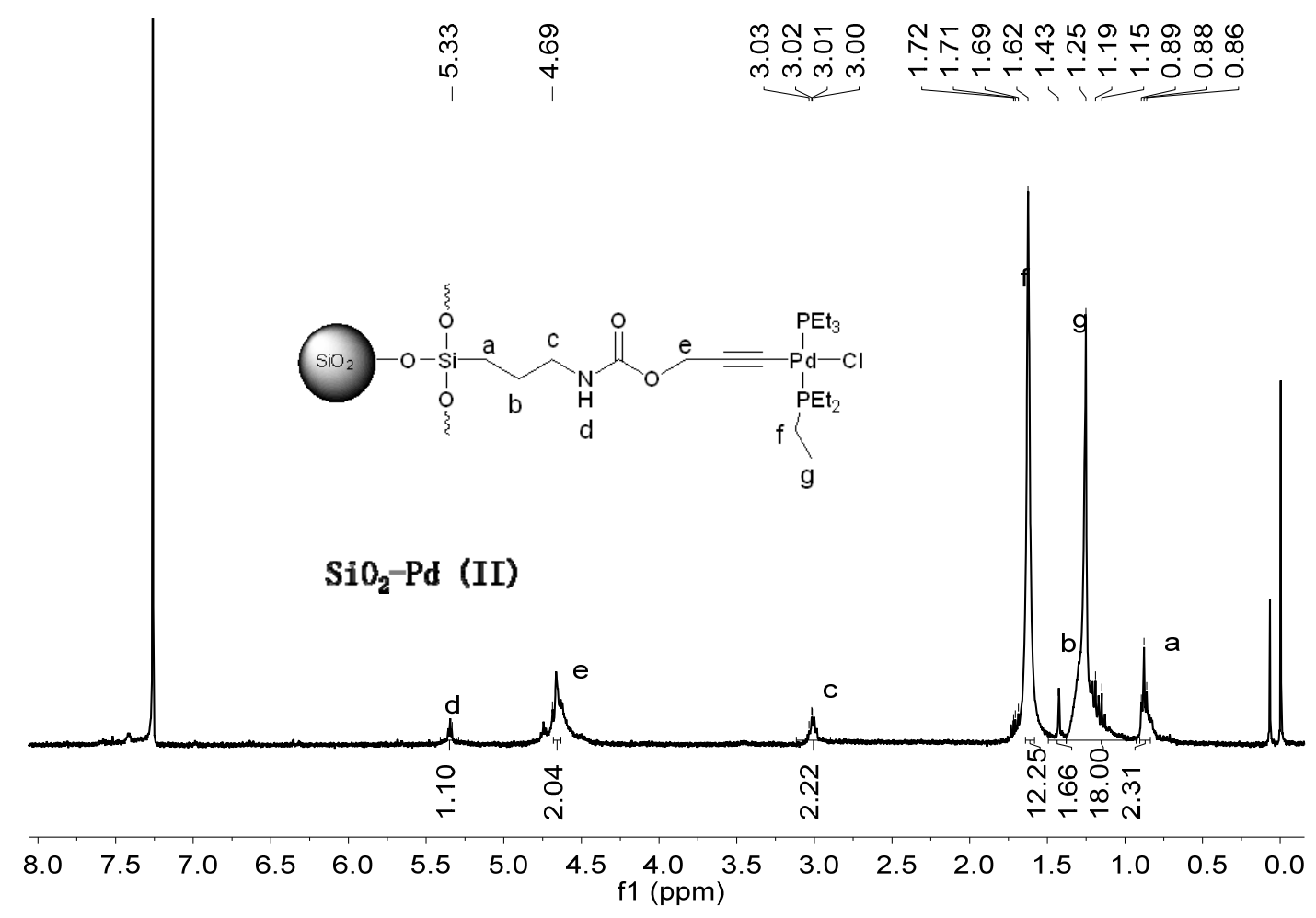

Figure S23. ${ }^{1} \mathrm{H}$ NMR spectrum of the $\mathrm{SiO}_{2}-\mathrm{Pd}(\mathrm{II})$ measured in $\mathrm{CDCl}_{3}$ at $25{ }^{\circ} \mathrm{C}(400 \mathrm{MHz})$.

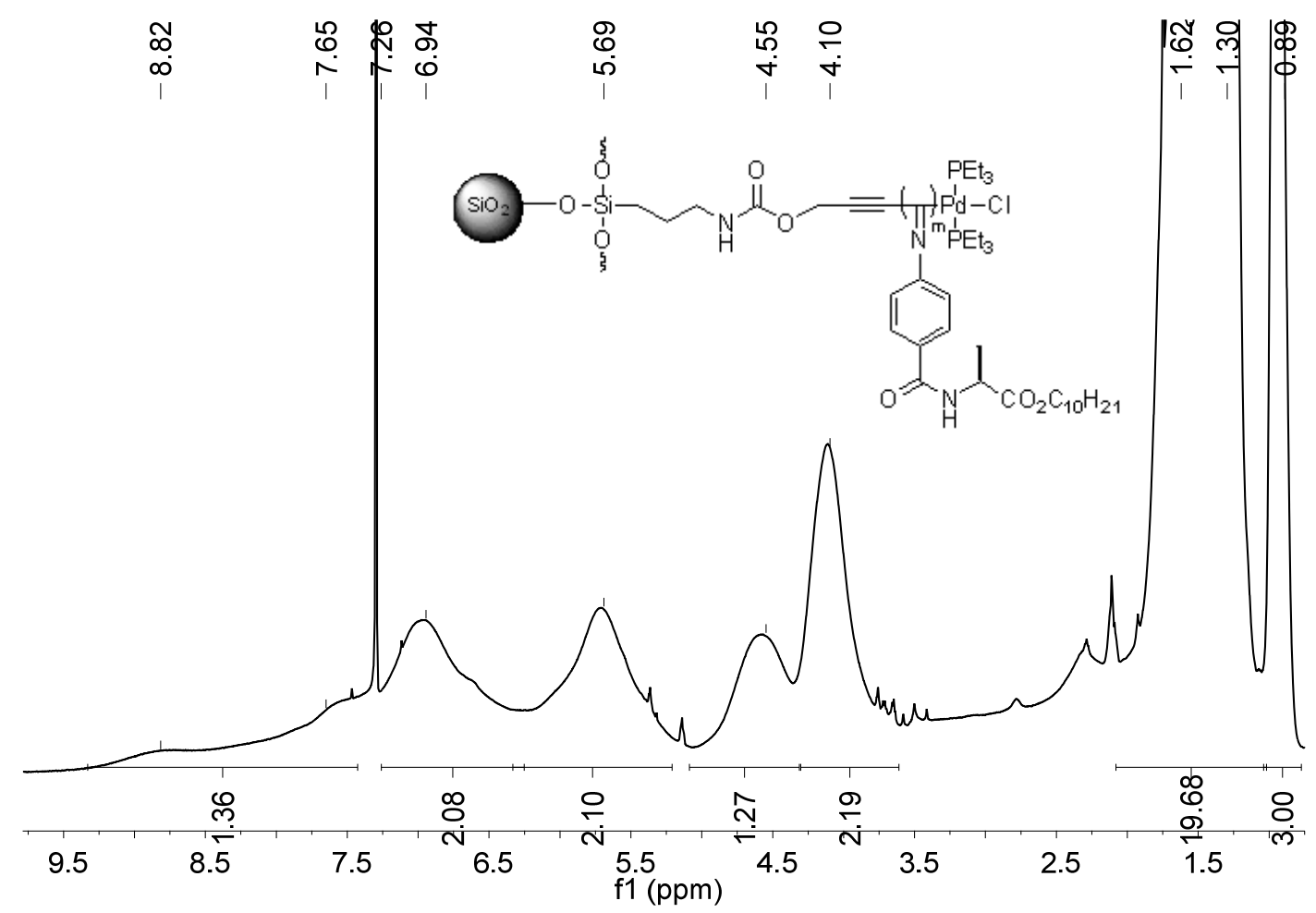

Figure S24. ${ }^{1} \mathrm{H}$ NMR spectrum of the $\mathrm{SiO}_{2}$-poly-2L100 measured in $\mathrm{CDCl}_{3}$ at $25{ }^{\circ} \mathrm{C}(600 \mathrm{MHz})$. 


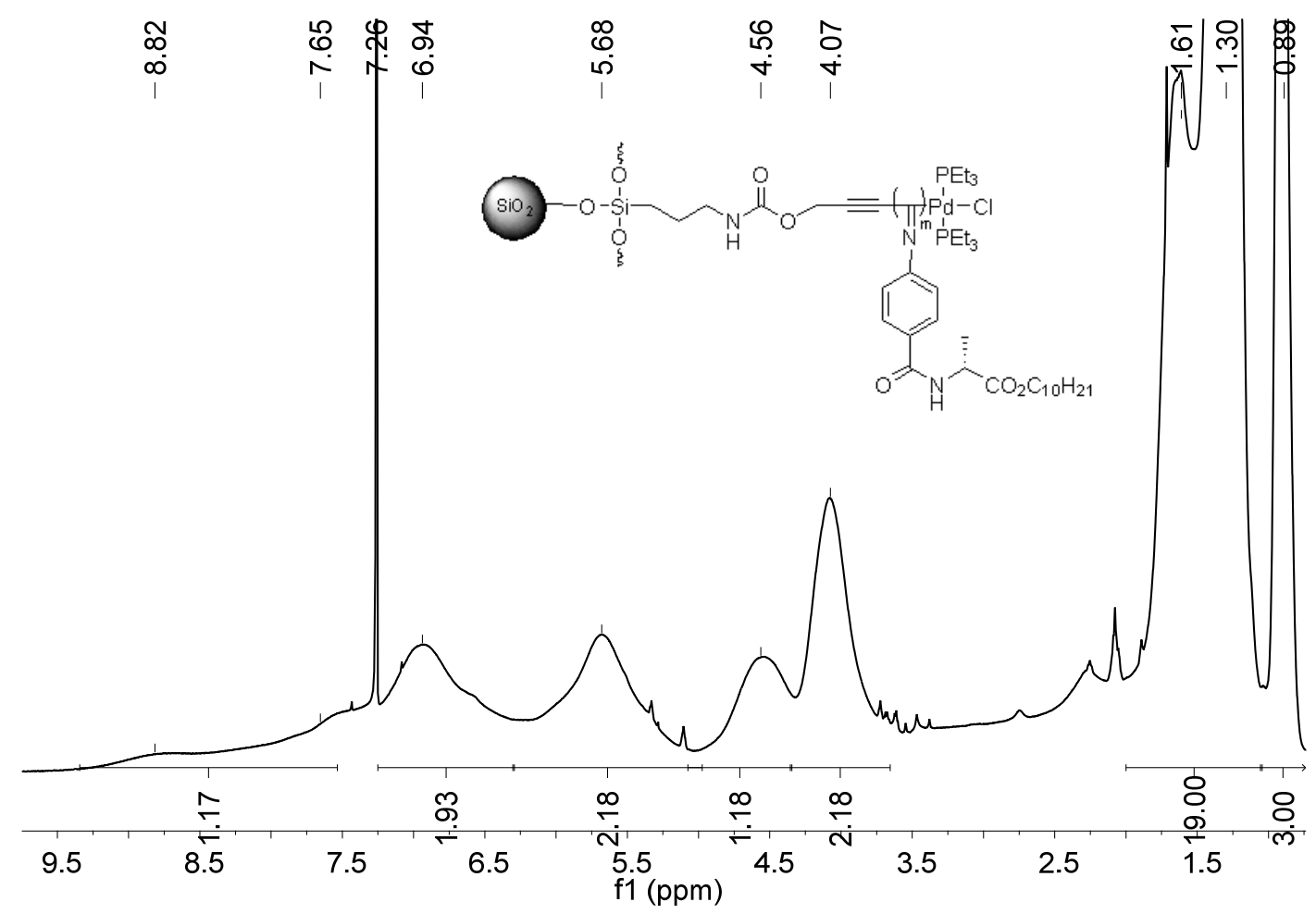

Figure S25. ${ }^{1} \mathrm{H}$ NMR spectrum of the $\mathrm{SiO}_{2}$-poly-2D 100 measured in $\mathrm{CDCl}_{3}$ at $25{ }^{\circ} \mathrm{C}(600 \mathrm{MHz})$.

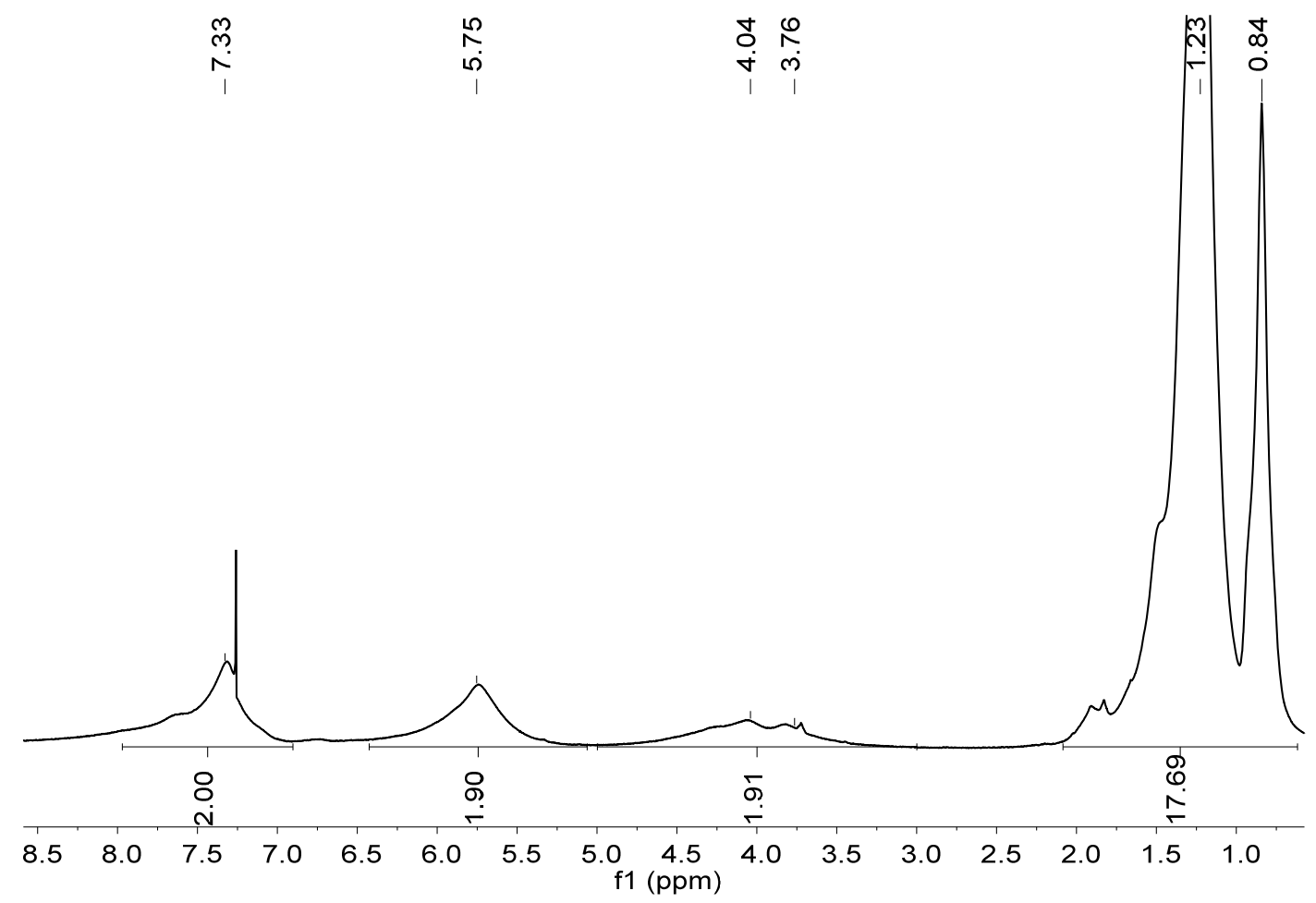

Figure S26. ${ }^{1} \mathrm{H}$ NMR spectrum of the poly-1 ${ }_{100}-\mathrm{SiO}_{2}$ measured in $\mathrm{CDCl}_{3}$ at $25{ }^{\circ} \mathrm{C}(600 \mathrm{MHz})$. 


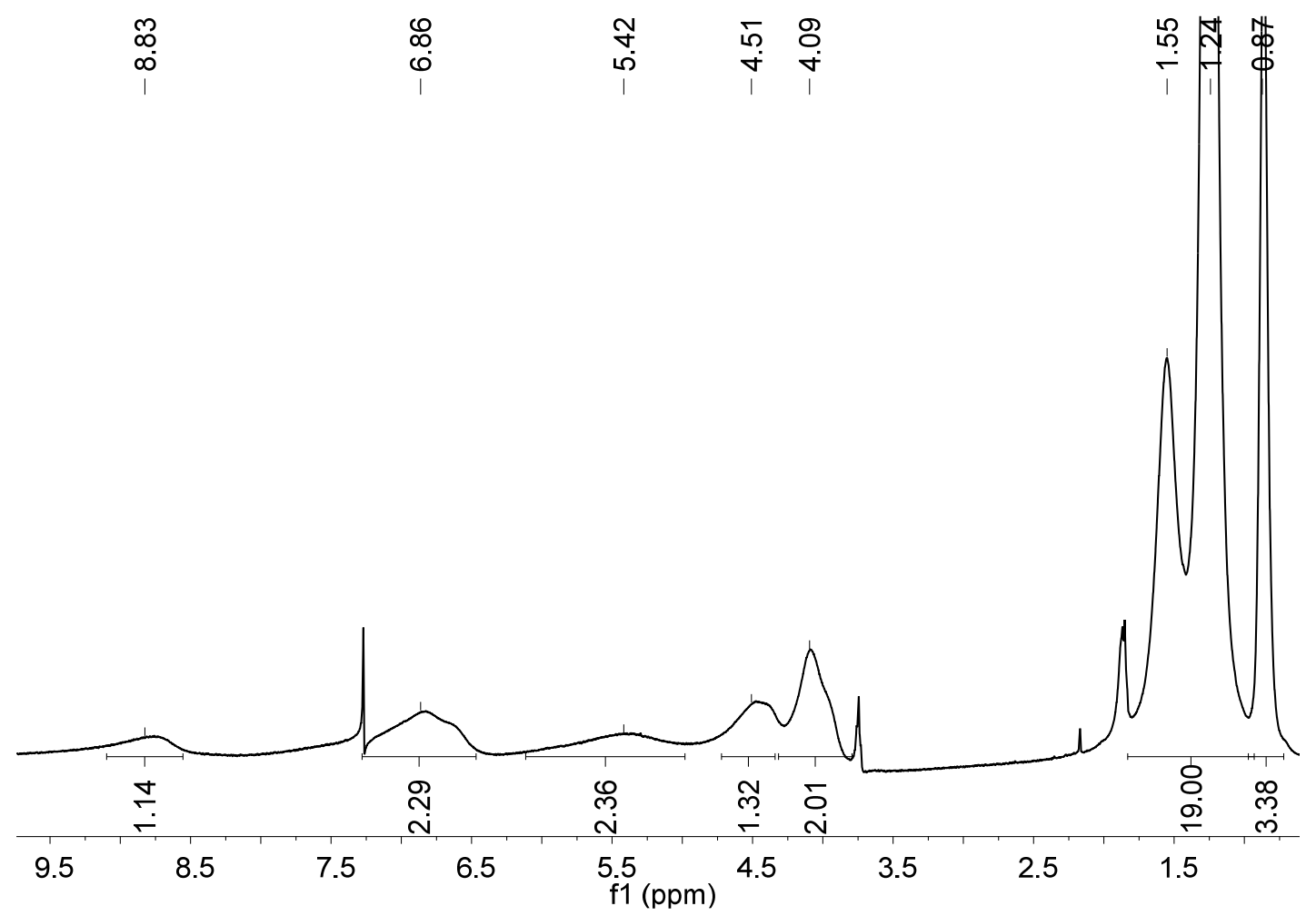

Figure S27. ${ }^{1} \mathrm{H}$ NMR spectrum of the poly-2 $\mathrm{L}_{100}-\mathrm{SiO}_{2}$ measured in $\mathrm{CDCl}_{3}$ at $25^{\circ} \mathrm{C}(600 \mathrm{MHz})$. 